\title{
Data Culture and the Organisation of Teachers' Work
}

Data Culture and the Organisation of Teachers' Work provides an in-depth look at how the political and media scrutiny of teachers, pupils and schools now organises teaching and learning. Spina also examines how educational data is used in schools, and where it fails to take account of the everyday experiences of school leaders, teachers and students.

Drawing on primary research, and discussing practice in relation to the National Assessment Programme: Literacy and Numeracy (NAPLAN), this book discusses the strengths and weaknesses of a data-driven approach, the restrictions this can impose and how to navigate them as a teacher.

Ideal for scholars and postgraduate students of education, this book provides a comprehensive institutional, ethnographic look into the daily lived experiences of teachers, and the effects of standardised testing.

Nerida Spina is a senior lecturer at Queensland University of Technology, Australia. 


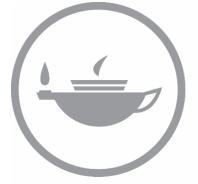
Taylor \& Francis Taylor \& Francis Group http://taylorandfrancis.com 


\section{Data Culture and the Organisation of Teachers' Work}

An Institutional Ethnography

Nerida Spina 
First published 2021

by Routledge

2 Park Square, Milton Park, Abingdon, Oxon OX14 4RN

and by Routledge

52 Vanderbilt Avenue, New York, NY 10017

Routledge is an imprint of the Taylor \& Francis Group, an informa business

(C) 2021 Nerida Spina

The right of Nerida Spina to be identified as author of this work has been asserted by her in accordance with sections 77 and 78 of the Copyright, Designs and Patents Act 1988.

All rights reserved. No part of this book may be reprinted or reproduced or utilised in any form or by any electronic, mechanical, or other means, now known or hereafter invented, including photocopying and recording, or in any information storage or retrieval system, without permission in writing from the publishers.

Trademark notice: Product or corporate names may be trademarks or registered trademarks, and are used only for identification and explanation without intent to infringe.

British Library Cataloguing-in-Publication Data

A catalogue record for this book is available from the British Library

Library of Congress Cataloging-in-Publication Data

A catalog record has been requested for this book

ISBN: 978-0-367-17325-8 (hbk)

ISBN: 978-0-429-05619-2 (ebk)

Typeset in Bembo

by Taylor \& Francis Books 


\section{Contents}

1 Boom! And it's all about data 1

2 The datafication of education 30

3 The production of data $\quad 51$

4 Performance management of principals: Data is the only game in $\begin{array}{ll}\text { town } & 71\end{array}$

5 Principal responses: Data stories, data conversations and high yield $\begin{array}{ll}\text { pedagogies } & 87\end{array}$

6 Teachers' work: A life revolving around data 105

7 Institutional circuits: Intense and never-ending work 128

8 Implications and possibilities: Data cultures and the organisation of teachers' work

Index 


\section{Acknowledgements}

This research would not have been possible were it not for the generosity and honesty of the teachers and school leaders who took part in this research. Their dedication to their students and to their profession is incredible: I hope I have done them justice. I am forever amazed by the many wonderful teachers I know (Susan, I'm looking at you!) who are passionate about their work and give so much of themselves to their students, their families and their friends. Thank you for all the work you do.

There are so many others who have supported and inspired me along the way. In particular, I thank Barbara Comber and Val Klenowski for your mentorship and friendship. Your humble generosity, kindness and expertise are a rare combination. Jess Harris has also emerged in my life as a strong mentor, friend and advocate for justice - thank you Jess for your generosity and encouragement. I hope we find many more projects to work on together in the future. Thank you also to my library buddy John Raiti for your willingness to read drafts, chat about ideas and hang out with your wonderful family. Which library shall we visit next?

Finally, and most importantly, I am very grateful for the generous and careful editing provided by my daughter, Gabby. I put her writing and editing skills to work once again - the quality and precision of your contributions have made all the difference to the final product. I am also forever thankful for the support and encouragement of my daughter Lainey. You have provided endless assistance with reading, motivational pep-talks and philosophical discussions on the state of education. Salvo, you have always given me the time and space (and coffee and delicious cooking) to do this work. I am grateful for your unwavering support, and for the respect you have shown me as I have undertaken this work. A written acknowledgement can never encapsulate my gratitude, but this book is dedicated to you all. 


\section{Boom! And it's all about data}

Well my first comment is that data is the new, dirty four-letter word. You know, it was just like, BOOM! And it's all about data.

(Rosa, primary school teacher)

I guess my life revolves around data these days. It has to because it is everything.

(Jennifer, primary school teacher and head of curriculum)

I cannot continue to do a job that requires me to do what is fundamentally against my philosophy of how it should be done. I love my students and they love me. I know how to engage children in learning and how to make it fun. It's what I do best ... So why am I writing this? I'm writing this because teachers need to speak up but we are often afraid of retribution. We need to claim back our profession but we are powerless. Teachers teach because we love children and are passionate about education. Our young teaching graduates enter the profession bright eyed and bushy tailed, energetic and enthusiastic, ready to make a difference. So why I ask are they only staying for an average of 5 years? Of course that question is rhetorical. I know the answer. They are burnt out and disillusioned. Older teachers like me have seen better days in the classroom so in a way it's harder for us to see all the joy slowly being sucked out of learning. But we also have a wealth of experience to draw from and we know which hoops you don't necessarily need to jump through. We occasionally speak out. We are not as easy to "control". But we are tired and also burning out with disillusionment.

I write this in the hope that we can spark a public discussion. We need the support of parents, who I know agree with us. I write this because I love children and I can't bear to see what we are doing to them. Last year, as I apologised once again to my class for pushing them so hard and for the constant barrage of assessment, one child asked me "if you don't like the things you have to do then why are you still a teacher?" That question got me to thinking long and hard. I had no answer except that I truly loved kids and it was with a heavy heart that I realised that wasn't enough anymore.

(Kathy Margolis, former teacher)

Jennifer and Rosa are two teachers working in vastly different schools. The similarity of their experiences points to one of the most significant changes to educators' work in recent times - the use of data and numbers to drive 


\section{Boom! And it's all about data}

education policy and practice. Rosa, a primary ${ }^{1}$ school teacher with more than 30 years' experience, said that she was accustomed to "things coming and going" in education, and that during her career she had experienced a steady ebb and flow of policy change. Although she was used to seeing different approaches to curriculum and pedagogy come and go, it had become apparent to Rosa and her colleagues that although data was a "new 'thing' in the cycle of "things", something about this change was markedly different. By "data", Jennifer and Rosa were referring to the use of large sets of numbers such as student achievement on standardised assessment. Unlike curricula or pedagogic fads, data was underpinning a larger, more permanent paradigmatic shift in education. According to Rosa, a new data culture had emerged as the one "thing" that would not go away. "No way," she said.

The other account is a Facebook post written by former classroom teacher Kathy Margolis (2016) explaining her decision to leave teaching after some three decades. This post was much like that of another former primary school teacher Gabbie Stroud who also announced on Facebook that she had resigned from teaching, with a passionate discussion about how standardised assessment and data had transformed the job she had once loved, leaving her exhausted and dispirited (McKnight, 2015). During the same period that Margolis and Stroud began to voice their concerns about a culture that valued assessment and data so highly, many government and mainstream media reports continued to position standardised assessment and data as a necessary tool for understanding the inner workings of schools. Rather than listening to teachers' embodied experiences of working under such regimes, teachers' attempts to contest this approach were often dismissed by media pundits.

Much of the early media reporting in Australia following the inception of a national standardised testing program ${ }^{2}$ positioned teachers as lacking skills in the use of data to inform their teaching practice. For example, Ferrari (2011), writing in The Australian newspaper, described teachers as data "phobic", and as needing to be "dragged reluctantly" into debates about measuring student achievement because they were largely ambivalent about the value of measuring and analysing student test results. Similar media articles such as "NAPLAN tests too hard for teachers" (Morton, 2013) argued that an Australian Senate Committee report (2014, s.2.28) that recommended teachers be provided with training in data analysis and interpretation "represents a stinging rebuke of teachers who have mounted campaigns against the tests as being costly, inefficient and unhelpful" (Morton, 2013).

Despite being labelled anti-improvement, teachers continue to speak out and describe the effects of working in a culture that prizes data so highly. Both Margolis and Stroud have continued to discuss their views, and to advocate for teachers' beliefs about their work with children and young people. For example, Stroud's post provided her with a platform for television and radio appearances (e.g., Fidler, 2017; McEvoy, 2018), a journal paper (2016), and a book (2019) recounting her burnout and ultimate decision to leave the teaching profession. In a 2019 blog post on Mamamia.com ${ }^{3}$ entitled "It's a waste of time': 11 teachers and parents share what they really think of NAPLAN", comments such as this were posted: 
I'm both a teacher and parent. I despise it. It's one snapshot, on one day, which gives an indication of progress - not a definitive and overall view of ability. It helps schools to gauge how they are going, plan and reflect, but now government; parents; society; media place such a huge emphasis on it, it has changed meaning. My son will do it for the first time next year, and I'm thinking of taking a well-timed holiday.

These kinds of stories resonate with my own experiences of classroom teaching, education research and teaching in initial-teacher education programs. Talking with teachers and pre-service teachers from across Australia, I have noticed in the remarkable similarity of stories a culture that is dominated by data-collection and use. Many of these same teachers and school leaders have also talked about how they value the many advantages that are to be had from using data and evidence to inform their practice. I am often struck by the enormous dedication and capacity of teachers and pre-service teachers as they use data to refine and improve their practice. I note that the teachers who took part in this research were aware of the value of making evidence-based decisions.

However, as the above stories reveal, there is a divergence between the taken-forgranted discourses that politicians, the media and the public hold about teachers, teaching and data; and the embodied experiences of teachers and school leaders. Educators are often cast as part of a problem of declining standards (e.g., Mockler, 2019); with data proposed as the logical mechanism to monitor and ensure quality, and the justification for ever more education reform (e.g., Hunter, 2019). Their nuanced understandings about the benefits and perverse effects of working in a data culture are often missing from media and political discussions.

Teacher attrition and burnout are increasingly recognised as an international policy problem (e.g., Dworkin \& Tobe, 2014) that is related to the rise of standards and evidence-based accountability. While there has been some increase in the attention given to the embodied experiences of teachers (for example, through social media posts, and the tragic circumstances of educators such as school principal Trish Antulov who passed away at her desk at work (Mourad, 2018)), less attention has been paid to the disjuncture between official accounts of teachers' work as enshrined in education policy, and the everyday work of teachers. This book therefore begins with three questions: What are teachers' experiences of data in their everyday/night work? How is this work organised? And what are the effects of a datafied education system on teachers' work?

This book presents the findings from an institutional ethnographic investigation of the experiences of teachers and school leaders in Australian schools. Institutional ethnography is a research method of inquiry developed by Canadian sociologist Dorothy E. Smith who describes it as an "alternative sociology" that is not driven by pre-theorisation and the application of strict methodological processes (Smith, 1999). Rather, the research begins by inquiring into the actualities of the subject of inquiry; examining their everyday worlds. This research was designed to uncover what it really means to be a teacher working in a data culture. Smith's early work (e.g., 1974, 1987) highlighted how women's experiences and knowledge were 


\section{Boom! And it's all about data}

often missing from official accounts. The research method grew Smith's investigations into how ordinary, often-invisible domestic chores that women undertook allowed men to live in a world where "their work lives [were] untrammelled by responsibility for managing their mundane daily needs" (Campbell, 2003, p. 7). Everyday tasks such as cleaning babies' vomit, grocery shopping and preparing food are not glamorous, but are important to the functioning of family life.

Similarly, much of the work teachers do is vitally important to the functioning of education systems. Many of the teachers I talked with were surprised that I was interested in what they considered to be unimportant, mundane tasks that were almost invisible, even to themselves. According to Porter (2012), significant ethnographic research is needed to expose how numbers are both produced and used in modern institutions because its "boringness" means it often escapes examination, controversy or dissent. My hope is that this book will provide some insight into the range of work that teachers undertake, and to provide a space for examining and discussing the use of data in education. If we are to understand the operation of education in a datafied system, it is important to see all forms of teachers' work, in order to turn it "from its extraordinary invisibility into visibility" (Smith, 2003, p. 63).

Understanding teachers' work is important, although on its own, it doesn't explain why teachers in vastly different settings are voicing related concerns about their work in a datafied education system. The research in this book draws on the accounts of school principals and teachers in both primary and secondary settings in Australia; from high and low socio-economic areas; and from metropolitan and regional locations. The excerpts (above) from Rosa and Jennifer illustrate how two teachers at very different schools - one in a well-off metropolitan area and one in a school characterised by families struggling with unemployment and poverty - are working in remarkably similar ways. Examining the work of teachers such as Rosa and Jennifer is instructive, but on its own, does not explain why such similarities exist. Institutional ethnography as a research method is unique in that although it is grounded in the everyday experiences of real people (like teachers) in real places, its ultimate goal is to map the operation of complex, power relations that coordinate what happens in local settings. Without examining these broader structures it is difficult to understand how we have arrived at a situation in which the stories of Rosa, Jennifer and their teaching colleagues (along with the growing chorus of teachers and leaders on social media) bear such striking similarities.

These trends are not unique to Australia. Finnish educator Pasi Sahlberg (2007) has described the spread of standardisation and large-scale testing as a GERM (Global Education Reform Movement) that has infected education policies worldwide. In this book, I explore how these global and national policy assemblages orchestrate the work and lives of teachers and school leaders, and with what effects.

To disrupt the dominant view in media and policy discourses that data is an obvious and objective way of understanding and managing education, it is worth reflecting on how we arrived at this moment. In this introductory chapter, I therefore provide a history of quantification and the datafication of education. The chapter concludes with an outline of the book. 


\section{Data and global education policy}

Numbers have not always been used to measure and manage education. Although evidence-based decision making may now seem a logical means of understanding education, the explosion of these practices is a relatively recent phenomenon (Lawn, 2009). For example, in

the 1800s, World Fairs and Expositions used rich descriptions of pedagogy, highly detailed accounts of planning, curriculum, resourcing and even schoolroom layouts. In 1893, author Robert Bancroft described the education exhibits at a World Exposition in Colombia:

Here may be compared the [education] systems of countries many thousands of miles apart ... all grouped within a few thousand yards of space, and yet presenting a clearer illustration of methods, appliances and results than could be obtained from an extended tour of the world.

(Bancroft, cited in Sobe \& Boven, 2014, p. 5)

Although there were no quantified, standardised measures, these accounts "gave the reader the distinct impression that [a particular system, frequently the American school system] was the best" (Landahl \& Landahl, 2009, p. 60). This kind of description was a precursor to the contemporary discourses that are based on similar assumptions about the importance of comparison.

International comparisons of education systems have moved from narrative description to judgements based on standardised, numeric data. Examining media stories across the decades from the late 1800s onwards illuminates the difference in how comparisons between education systems were made, and how these were increasingly quantified in the latter part of the twentieth century. An editorial published in Brisbane's Telegraph in 1918 begins with a general description of the state of education, much like we might read in contemporary media reports, although it included the insight that:

To some extent, that statement [that the current education system needs improvement] will always be the truth. The world will never hear the last word about education, because in the nature of it and in the circumstances and conditions which surrounded it there can be no last word. An absence of satisfaction with what has been, or is being achieved is a sure sign of progressive improvement.

(Education, 1918, p. 6)

The article goes on to describe the complexities of evaluating education systems by focussing on the comparative international judgements that had positioned Germany as the best education system in the world prior to World War I. It argues that both Germany's technically superior education system, and Russia's poor education system failed to produce citizens capable of either halting the rise of Nazism and communism, or of winning the war. The article concluded 
that, "the lesson of the war is that education is only protective in the full sense to a nation when it is associated with character as well as with mind" (p. 6). The only quantified data in the article are in reference to the approximately "seventy or eighty per cent" of the Russian population who were deemed illiterate. Comparative judgements continued to be made over the next five decades, using similarly narrative accounts.

While rich narrative description and photographic accounts had once been considered appropriate, states began to rely on quantified datasets during the rise of modernity and urbanisation (Grosvenor \& Roberts, 2009). In the late 1880s the first education censuses were undertaken for a variety of purposes. For example, in the U.K. early census data collections were undertaken by School Attendance Officers to identify "all imbeciles, idiots, epileptics or feeble-minded among children of school age" in order to ascertain school accommodation requirements (Grosvenor \& Roberts, 2009, p. 82). The purpose of this data was to inform funding decisions. This data collection was made possible by a priori decisions about who and what to count, and how to constitute populations. While categories such as "imbeciles" and "idiots" are unpalatable in modern times, they demonstrate that categories are socially constructed; and that these decisions allow for measurement of populations for specific purposes such as funding.

The use of numbers as a mechanism to both account for education and to allocate funds has been in play in many Western countries since at least the early twentieth century. For example, in the early 1900s the U.S. introduced large-scale literacy testing programs as part of its recruitment practices for World War I. By the 1920s, almost all American school children were being assessed with standardised, norm-referenced tests (Luke \& Van Kraayenoord, 1998).

The rise of Tayloristic practices in education was intimately entwined with quantification. Taylorism is named after Frederick Taylor, the American businessman who transformed manufacturing work by using time and motion studies to increase efficiency. Simon Patten, a prominent reformer of the early 1900s, argued that statistics could be used to measure the efficiency of a range of workers from sanitation workers to teachers. He asked, "why should New York spend its money on schools instead of on subways, parks and playgrounds? Why should it support inefficient teachers instead of efficient milk inspectors?" (cited in Callahan, 1962, p. 48). The result was a shifting focus from equity to accountability and cost-cutting, where the key was implementing systems that allowed education to be "readily seen and measured" (Callahan, 1962, p. 48).

An upsurge of quantification and comparison emerged in the 1980s as global momentum grew for wider neoliberal agendas, including the promotion of marketised solutions to education systems that were purportedly in crisis (Lipman, 2016, p. 21). By the turn of the twenty-first century, the U.S. had embarked on a major benchmarking program, known as "The New Standards Project", which assessed almost half of American school children according to "international benchmarks" (Shannon \& Edmondson, 1998, p. 45). Moves towards quantification have continued unabated, for example under the Bush administration's "No Child Left Behind" and the Obama administration's "Race to the Top" programs. 
This discursive shift towards valuing large-scale assessment data was also evident in Australian education policy and media reports. A 1983 article in The Canberra Times reported on the state of U.S. education by citing the federal education policy "A Nation at Risk". The article described that a so-called "tide of mediocrity" was evidenced by quantitative data including international comparisons of student achievement, in which "on 19 academic tests American students were never first or second and, in comparison with other industrialised nations, were last seven times" (p. 2). The article went on to describe that the "average achievement of high school students on most standardised tests is now lower than 26 years ago when the U.S.S.R. launched the first spacecraft, Sputnik, prompting a boom in American science education" (p. 2).

Moving into the 2020s, media reports continue to rely on large data sets to underpin the public's understanding of schooling. In a Forbes (2019) article titled "10 Moments That Capture a Decade in Education", Hess (2019) described that despite "frenetic" reform efforts across the U.S. that sought to improve National Assessment of Educational Progress data, that "the 2010s were a decade marked by grand aspirations and more than a little disappointment".

\section{PISA and global testing}

A further significant shift has been the move towards international quantification that enables comparison across national boundaries. One of the key drivers of global education policy has been the rise of large-scale, globalised testing programs such as the Programme for International Student Assessment (PISA), which is run every three years by the Organisation for Economic Co-operation and Development (OECD). PISA's history is relatively recent, having commenced in the Year 2000, with just 43 education systems participating. Although 2018 marked only its seventh occurrence, it has not only grown in size (with 79 participants in 2018) but has also become central to education policy, discourse and research around the world (Lewis, 2014). The following statement made by Andreas Schleicher (2013) (Director of the Education and Skills Directorate, OECD) is typical of discourses that privilege numbers as an objective way of understanding and comparing education systems:

PISA has ... helped to change the balance of power in education by making public policy in the field of education more transparent and more efficient.

(Schleicher, 2013, para. 5)

PISA data is frequently used to create hierarchies and league tables in which there are clear winners and losers in the global education race or marketplace. As global testing regimes have gained traction, governments and policy makers have used this data to enable further reform. Sellar and Lingard (2013) describe the use of "reference societies" as a means of producing "PISA shocks". In the 2009 round of PISA testing, Shanghai emerged as a significant new reference society, that was seen by countries such as Australia, the U.S. and the U.K. as 
"winning" the education race (as described by both U.S. President Obama and Australian Prime Minister Gillard) (Sellar \& Lingard, 2013, pp. 472-478). The release of 2012 PISA data was reported in Australia under headlines such "PISA report finds Australian teenagers worse than 10 years ago" (Bita, 2013).

These trends have continued, although within the context of new mediascapes. Baroutsis and Lingard's (2019) research returned 200,022 tweets with the search term "PISA" between 19 November and 31 December 2016 (p. 33). In addition to the explosion of social media to report and comment on trends such as PISA, traditional media continue to use international data to write about the state of national education. Following the release of 2018 PISA data in late November 2019, the Australian media landscape was awash with headlines such as "PISA 2018: Australian school scores fall on the world stage" (Groch, 2019) and "Let's get back to basics" (Pendberthy, 2019) that reported on Australia's "plunging" international standing. Internationally, articles such as "'It Just Isn't Working': PISA Test Scores Cast Doubt on U.S. Education Efforts" (Goldstein, 2019) in The New York Times show that the discourses of shock continue in contemporary times.

Lingard and Sellar's (2013) notion of data-led "moral panic" is exemplified in the reporting of media outlets where sensationalist headlines, interactive maps and league tables graphically represent the "problem" of poor performance and lack of competitiveness (e.g., Stevens, 2019). It is worth mentioning that these kinds of media reports do not recognise complex social, economic, political and cultural variables when comparing countries based on large-scale standardised assessment data. The stories present data that is only the tip of the iceberg without explaining what is below the water-line. For example, in 2015 Australian PISA data compared unfavourably with that of Vietnam. A deeper dive reveals that the OECD's decision to test "in school populations" in PISA has a significant impact on data. In Vietnam, this means more than 51\% of 15 year-olds were not eligible to be included in the 2015 PISA assessment round (Jerrim, 2017), with the poorest, and poorest performing students being most likely to have left school by the time they are 15 . This stands in stark contrast to the Australian population sample which was over $90 \%$ of 15 year olds in the same year. Removing the same proportion of students from the Australian sample would clearly have a significant effect on overall PISA results. Without reporting on these nuances, media articles serve to expand dominant discourses in which numbers and data are seen as a neutral, objective and scientific means of representing student learning and achievement.

The notion of deliberately using or manufacturing a crisis to enable reform grew out of Milton Friedman's neoliberal ideologies developed at the Chicago School of Economics (Klein, 2008). Friedman explained that "only a crisis - real or perceived - produces change" (cited in Klein, 2008, p. 6). In his late nineties, Friedman (2005) wrote a piece for the Wall Street Journal in which he proposed further neoliberal education reforms in the wake of Hurricane Katrina in New Orleans: 
Rather than simply rebuild the destroyed schools, Louisiana, which has taken over the New Orleans school system, should take this opportunity to empower the consumers, i.e., the students, by providing parents with vouchers of substantial size, say three-quarters of per-pupil spending in government schools, usable only for educational expenses. Parents would then be free to choose the schooling they considered best for their children. This would introduce competition, which is missing from the present system.

The use of a shock to enable privatisation "accomplished in one day ... what Louisiana school reformers couldn't do after years of trying” (American Enterprise Institute, quoted in Klein, 2007, p. 7).

Policy makers and politicians have increasingly used global datasets, most commonly PISA, to justify national reform efforts. For example, in 2013, ABC News (as well as various other media outlets) reported federal Education Minister Christopher Pyne as saying, "these are the worst PISA results since PISA began in 2000 .... They are a serious wake up call for the Australian education system" (Bita, 2013). The transformation of educational data into truths about the "problem" with education could be used to justify further neoliberal and neoconservative policies such as a renewed focus on teacher quality (to be measured with even more data), a back to basics curriculum and school autonomy. These neoliberal policy discourses are part of what Novoa and Yariv-Mashal (2003) describe as a new "global policyspeak", or the emergence of neoliberal policy borrowing on a global scale that is linked to new forms of public management and "steering at a distance" (Kickert, 1993). As Porter (1996) has argued, policy makers have a "strong incentive to prefer precise and standardisable measures to highly accurate ones" (p. 29) because numbers can become reified facts that are able to inscribe the complex embodied realities of real life into categories that allow for technologies of governance to operate (Rose, 2003).

As Biesta (2015) reminds us, numbers such as PISA data have no intrinsic power, but "become powerful because people seem to believe in it" (p. 358). Despite the OECD having no direct influence over national education policies, member and non-member states are willing to invest in the OECD's operations, which represents the "soft law" or "bottom up" power of global education policy (Biesta, 2015) in which there are shared understandings around education: for example that education can be quantified in useful ways; that quantification enables better management of education and improves effectiveness; and that quantification improves social justice outcomes. W. Smith (2016) has argued that a "global testing culture" has emerged in which high-stakes standardised testing is now accepted (and sought after) as a foundational education practice.

Neither the government nor the mainstream media reporting of PISA engages in serious or ongoing debate about the validity of the PISA data or ranking system, despite methodological concerns about the conduct, analysis and interpretation of PISA results having been raised in academic literature (e. g., Goldstein, 2004). Regardless of these ongoing debates, PISA continues to 
expand both in scope (i.e., what is measured), scale (i.e., by increasing the number of participant countries, systems and schools) and the explanatory power data is afforded (Sellar \& Lingard, 2013).

These global changes have also increased momentum for national assessment from the mid-1990s. As W. Smith (2016) describes, the concurrent growth in national and international testing practices that have occurred over the past two decades are complementary, and can be seen as part of an emergent global testing culture.

\section{Australia moves towards datafication}

\section{The problem of quantifying education}

Comparable national education data was first collected in the early censuses of the Australian colonies in 1881, 1891 and 1911. The first national census measured citizens' level of schooling, asking them to indicate if they were "receiving education" (ABS, 2001) at a university, school, home-school or private school. The census also attempted to quantify citizens' education level by asking them to indicate if they could read and write. The instruction on the census card was:

Line 13. - Write CR for cannot read, R for read only, and RW for read and write. If not able to read English, but able to read a foreign language write RF and if not able to read and write English but able to read and write a foreign language write RWF.

(ABS, 2001, p. 426)

Comparing this question with contemporary quantification of literacy practices is illuminating. Current views about what constitutes literacy and how it can be measured rely on purportedly objective standardised literacy tests. Yet, as these early attempts at collecting education data show, the categories that are used are important. This early census collected used categories such as location, gender and race. However, what is not made clear in the statistician's report is how these categories were created, or by whom. The categories, which included "full-blooded aboriginal", "Chinese half-caste", " "unmixed' marriages", "deafmutism" [sic] (ABS, 1911), demonstrate how entwined a priori categorisation decisions allow measurement to occur, but mask the "magic" and morality (Bowker \& Star, 1999, p. 9) that makes measurement possible. This early measurement of the literacy of a nation, collected by asking individuals to provide a subjective indication of their ability to read and/or write, is at odds with current practices that foreground technical measurement and objectivity. The 1911 census also asked citizens to indicate their highest level of educational attainment, with the census card asking: 
If the person to whom the card relates has obtained a University degree, state the degree, and give the name of the University and country in which it was obtained.

(1911, p. 166)

This early attempt to measure education was withdrawn, with the statistician's report indicating that the statistics were unable to be published because they lacked validity and reliability:

Not only were there many cases in which known holders of degrees had failed to furnish the desired information, apparently through failure to carefully read the instructions, but there were many cases in which existing and non-existent degrees of existing and non-existent Universities were recorded as possessed by persons whose acquaintance with a University must have been a negligible quantity.

(1911, p. 166)

These census cards were ultimately not processed because "the tabulation of such data would not only be labour wasted, but would actually be misleading" (1911, p. 166). The statistician's report also noted that the question that asked people to indicate whether they could read or write was unhelpful given that "with the enforcement of compulsory education the number of cases in which persons reach mature age unable to read is necessarily very small and relatively insignificant" (p. 167). This view about the need to quantify the basic literacy skills of a nation is interesting given the current focus on increasing data collection globally.

It was more than five decades until Australia again attempted to collect education data via the 1966 census (ABS, 2001). The difficulty of measuring this social construct again became clear, as the population once again failed to accurately comply with census instructions. Poorly worded questions on the census meant that the data collected was (once again) unable to be utilised (ABS, 2001).

\section{Funding, assessment and data}

The large-scale quantification of Australian education has largely been enabled by a sustained push for federal involvement in education policy despite the fact that it is a state responsibility. The Australian Constitution does not make specific reference to education, and the federal government has no authority to legislate outside its constitutional powers, nor to allocate money beyond "the purposes of the Commonwealth" (s. 81). However while states and territories are burdened with the provision of costly portfolios including health and education, the federal government has a greater ability to raise revenue than the states. Australia thus has a "high level of vertical fiscal imbalance" (Twomey, 2014, p. 2) in which the Commonwealth raises more revenue than needed to fund its responsibilities; and the states and territories raise far less than needed to fund their responsibilities. 
The Constitution does however provide the Commonwealth with the power to "grant financial assistance to any state on such terms and conditions as the Parliament thinks fit" (s. 96). Because the Commonwealth also has authority to place conditions on such funding, states and territories are in an inherently weak bargaining position (Cumming \& Mawdsley, 2012). This complex arrangement has created a so-called "blame game" (Twomey, 2014, p. 2) in which both tiers of government accuse each other of failures in service provision in key areas including education. These federal-state relations have had a significant impact on the explosion of data collected at the national level, because federal assistance has increasingly been tied to the implementation of standardised assessment and data, and the achievement of benchmarks and targets. NAPLAN is one such example, with other policies such as the National Consistent Collection of Data on Students with Disability (cf. Gallagher \& Spina, 2019) requiring significant data collection as part of federal state funding arrangements.

Australia first attempted to use student assessment to quantify literacy and numeracy achievement at the national level via two sample surveys in the 1970s and 1980s. The official reports noted that Australia was following international trends, for example, by citing examples such as the U.S's "A Nation at Risk" (e.g., Rothman, 2002, p. 61). These trends continued through the 1980s, with the federal government's Quality of Education Review Committee (Karmel, 1985) arguing that education funding should move from inputs to outcomes, in order to ensure "value for money" (p. 2) and increase education quality. The report argued that a lack of "established mechanisms for systemic recording of output information" (p. 25), meant governments lacked information about how funds were allocated, and, therefore argued for a move towards large-scale national testing, particularly in the areas of literacy and numeracy.

In 1989, a historic agreement was struck between the Commonwealth and State Education Ministers that included agreement to a set of national goals for schooling. The "Hobart Declaration on Schooling" (Australian Education Council, 1989) was the first cooperative declaration of its kind and included commitment to a process for mapping minimum standards in literacy (Australian Education Council, 1989). The inaugural report (Australian Education Council, 1989) argued that if Australia was to make progress towards achieving any of its education goals, "relevant statistical data, where it is nationally comparable" and approved "national sample studies" would be used, and "of particular national significance" (p. 5).

National goals were further developed throughout the 1990s with Australian states and territories each agreeing to conduct their own literacy and numeracy assessment programs (Ainley, 2002). In 1992, a further step was taken towards formalising state/territory and federal cooperation, with the establishment of the Council of Australian Governments (COAG). COAG has been central to the operation of cooperative federalism since its inception. For instance, in 1993, COAG commissioned a review of government-funded education (Steering Committee for the Review of Commonwealth/State Service Commission, 1995). The review used the National Goals for Schooling in Australia 
to examine efficiency (cost per student) and effectiveness of learning outcomes and equity. The ongoing lack of consistent data across the country was instrumental in moving Australia further towards nationally comparable data, and the ultimate decision to move towards a national census-style assessment program.

There were significant debates occurring amongst educators during this period. For example, as national benchmarks were developed there was discussion about the difficulties associated with defining "minimum standards". For instance, Margaret Gill (1998) described her attendance at a federal government forum to discuss the new national approach to literacy and benchmarking. Her reflections on the challenges of quantification are insightful:

Can one set of benchmarks accommodate cultural difference? How useful can such benchmarks be when divorced from a whole school literacy strategy? Can they avoid the risk of specifying arbitrary grammatical features when divorced from any coherent discursive framework? Do the benchmarks define standards at all? (How, for example, do you measure the difference between a 'developed idea' and a 'clear and developed idea'?) Are benchmarks, in fact, covert and prescriptive curriculum statements? The Taskforce team did indeed have a difficult task ahead of them.

Here, the problems of measurement, averages and classification become evident. The issues raised by Gill are reminiscent of the problems experienced almost a century earlier by Australian census writers as they sought to create workable and measurable categories and definitions of literacy. In 1998, Curriculum Perspectives, the journal of the Australian Curriculum Studies Association, published a collection of papers on benchmarking in which the editorial noted that "educational historians may well look back on the 1990s as the decade in which benchmarking emerged as a major movement in educational planning and discussion" (Christie, 1998, p. 43) with numerous papers in the issue noting similarities between Australian, U.S. and U.K. education policy developments (cf. Leung, 1998; Shannon \& Edmondson, 1998). At the time, concerns about benchmarks included that articulating essential skills in curriculum areas was fraught (cf. Luke \& van Kraayenoord, 1998); that large-scale testing and norming using benchmarks would undermine quality pedagogy and inevitably drive (and narrow) curriculum (cf. Leung, 1998; Willis, 1998); that these changes would have damaging effects on the most vulnerable groups of students (cf. Willis, 1998); and that systems of "payment by results" were a likely consequence of benchmarking (cf. Luke \& van Kraayenoord, 1998). These critiques of early attempts of benchmarking are particularly interesting given the subsequent rise of large-scale normed assessment in Australia, and the use of averages and benchmarks as important funding levers.

In 2004, the conservative federal government enacted the Schools Assistance (Learning Together-Achievement Through Choice and Opportunity) Act. To receive federal funding, each state and territory was required to enter into an agreement that provided the federal government with the ability to withhold or 
delay payments if conditions - including administering standardised literacy and numeracy testing for all students in Years 3, 5 and 7 - were not met. By 2005, the Schools Assistance Act Regulations (2.7, subsection 19 (4) of the Act) required that every child in Years 3, 5, 7 or 9 who attends school must sit the common national test in literacy and numeracy. Quantification and international comparison was enshrined in the Act's 2009 Regulations, which made direct reference to international data, including PISA and TIMMS (e.g., Regulation 3.1 includes measures such as "The percentage of students achieving at or above the standard in the PISA mathematical literacy assessment for 2009 and 2012”).

\section{National testing and data}

The National Assessment Program - Literacy and Numeracy (NAPLAN) commenced in May 2008, testing all students enrolled in Years 3, 5 and 7 across four domains: reading, writing, language conventions (encompassing punctuation and grammar) and numeracy. NAPLAN was introduced as part of the federal government's "Education Revolution” (Rudd \& Gillard, 2008). Justifications for this reform once again included international data such as PISA. For example, citing Australia's relative and absolute decline in reading performance between 2003 and 2006, and Australia's inequitable education 'system' which was described as a "long tail of underperformance" (p. 16). The policy argued that the reform agenda needed to establish "effective transparency and accountability mechanisms in schools that meet the needs of parents, policy makers and the broader community" (p. 5).

Cooperative federalism was furthered with the establishment of a National Curriculum Board in 2008, which was expanded in 2009, and renamed the Australian Curriculum, Assessment and Reporting Agency (ACARA). ACARA was established under the Australian Curriculum, Assessment and Reporting Authority Act (2008). Part 2 Section 6 (c-e) of the Act tasks ACARA with the responsibility to:

- collect, manage and analyse student assessment data and other data relating to schools and comparative school performance.

- facilitate information sharing arrangements between Australian government bodies in relation to the collection, management and analysis of school data

- publish information relating to school education, including information relating to comparative school performance.

The Intergovernmental Agreement on Federal Financial Relations (COAG, 2009), further cemented cooperative federalism, basing significant federal funding on state and territory achievement of quantified performance measures. Changed funding arrangements have continued to cement the importance of data in education policy. For example, between 2008/09 and $2011 / 12$, the National Partnership for Literacy and Numeracy was worth $\$ 540$ million, with the states and territories committing to a similar contribution. 
This model allocated included funding for "achievement of implementation milestones", along with "reward funding" for the achievement of negotiated targets (cf. COAG, 2008). Many of the targets in The National Partnership bilateral agreements were NAPLAN indicators such as the percentage of students at or above the National Minimum Standard (NMS) and Mean Scale Scores (MSS).

Although the National Partnership agreements were bilaterally negotiated between the federal government and states/territories, each jurisdiction was required to agree to targets that the federal government deemed to be "sufficiently ambitious" (Lingard \& Sellar, 2013). These decisions were consequential for states. For example, despite achieving better results than Queensland in 2019, Victoria failed to achieve their more ambitious targets, and hence did not receive their full reward funding. Lingard and Sellar's (2013) research into the negotiation of targets reported that one Victorian policy maker suggested there had been no transparency in how agreements were being negotiated. Hence while Queensland had used its poor 2008 data as a baseline, and met its 16 targets, Victoria only met 5 of its 32 targets - despite having achieved better NAPLAN results.

Alongside a raft of complexities, the use of numeric data as a means of allocating funding and creating accountabilities demonstrates Porter's (1996) ethic of "thin prescription" (p. 595) in which institutions (or people) are judged by numbers, with the intention of ensuring transparency, fairness and accountability. As Porter argues, while thin prescription "sometimes works as a screen that protects [them] from the eyes of the curious", it almost inevitably leads to gaming in the form of negotiation and "shady manipulations" (p. 597). As the Commonwealth Grants Commission (2012) noted:

there was variation in the level of ambition of agreed targets across states. For example, Queensland agreed to reform targets for 2010 which were lower than their 2008 baseline. Queensland exceeded all its targets. In comparison, Victoria agreed to arguably more ambitious targets for 2010 and agreed to a 2009 baseline.

Given the increasingly highly visible and high-stakes nature of NAPLAN results, it is unsurprising that state governments prioritised serious efforts to improve NAPLAN data over coming years. Queensland's response is provided as an illustrative example.

\section{Queensland's response to 2008 NAPLAN data: Maximising achievement}

The changed federal-state relationships that had been established over the past decades had caused significant change at the state level. Because federal funding was closely tied to national testing and reporting from at least 2008 onwards, it is perhaps unsurprising that it became a significant policy driver at the state level. In 2008, Queensland's NAPLAN results were reported as: 
Queensland had a greater proportion of students below the National Minimum Standard (NMS) than the Australian average (for all years and all domains except year 7 numeracy).

Queensland was ranked second lowest in the country (just ahead of the Northern Territory) in all years and all test domains on the proportion of students at or above the NMS.

Queensland had more students in the lower two bands and less in the upper two bands for each year level and each test domain.

(Queensland Government, 2009

In response, the Queensland Government had commissioned a review, led by Professor Geoff Masters, the Chief Executive Officer of ACER. Masters' (2009) interim report recommendations included that:

last year's NAPLAN test materials be made available for classroom use by teachers of Year 3, 5 and 7 students early in the new school year. The purpose is to provide students with an opportunity to familiarise themselves with the NAPLAN testing materials and processes.

The state government accepted all recommendations and took immediate action to ensure that Queensland made improvements in the upcoming 2009 round of testing. The Department of Education and Training (cf. Masters, 2009, p. 56) developed a policy, Maximising Achievement Program which recommended "heightened test awareness" in schools by providing teachers and parents with access to 2008 NAPLAN test materials, instituting a compulsory practice testing regime and making item analysis from 2008 available to teachers. In the departmental annual report (2009) it was noted that, "more than 158,000 students sat the practice tests before 20 March in order to be better prepared for the 2009 NAPLAN tests held in May" (p. 3).

In May 2009 Professor Masters presented his final report, "A shared challenge: Improving literacy, numeracy and science learning in Queensland primary schools" (Masters, 2009). One consequence of the Masters Report was the development and implementation of the Queensland Education Department's Teaching and Learning Audit policy (Lingard \& Sellar, 2013). The instrument was developed by ACER and audits began in 2010, with schools scheduled for audit every four years. The document ranked schools against eight elements using a four-point scale: low, medium, high and outstanding. A number of the eight elements related specifically to either data use or improvement (e.g., analysis and discussion of data; an explicit improvement agenda). Some of the indicators of "low" achieving schools included schools where: "minimal attention is paid to data (e.g., NAPLAN results)", and "the principal is more focussed on day-to-day operational matters than analysing and understanding school data, setting targets for whole school improvement" (Masters, 2010, p. 2). 
As the audit regime was implemented, the results were reproduced as a league table in a local newspaper The Courier Mail (http://media01.couriermail. com.au/extras/12-1-29-Audits2011.pdf) along with articles such as "Report card: How your school stacks up" (Chilcott, 2012b). In addition to these external pressures, there is evidence that pedagogical choices available to teachers were impacted by Teaching and Learning Audits. For example, it has been reported that some schools (for instance those that had achieved "low" results on Teaching and Learning Audits) were instructed to adopt the departmental "Curriculum 2 Classroom" lesson planning materials more closely (e.g., Chilcott, 2012a; Kennedy, O’Neill, \& Devenish, 2011; QTU, 2012).

The use of NAPLAN as a driver of state education policy has continued since NAPLAN's inception. By 2012, the Queensland Department of Education, Training and Employment had devised and implemented United in Our Pursuit of Excellence (DETE, 2011), a policy which situated the NAPLAN domains (reading, writing, spelling, grammar and punctuation, and numeracy) and science (as recommended by Professor Masters' review which reported on Queensland's poor TIMMS (Trends in International Mathematics and Science Study) results) as a priority. The improvement focus also extended to attendance measures. The policy provided a differentiated model for supervision of school principals based on school achievement. According to the policy, this would be achieved through "an unrelenting focus" on improved student achievement (p. 1). NAPLAN data was further cemented as a key accountability measure that would enable the departmental centre to "steer at a distance" (Kickert, 1993), through regional offices.

By 2010, Queensland's intensified performance management and "unrelenting" focus on improvement meant that the state was able to achieve $100 \%$ of its \$48.5 million NAPLAN reward funding. However, Queensland's 2011 NAPLAN results failed to meet a number of targets, and reduced the state's reward funding by approximately seven million dollars. In 2012, Queensland received $\$ 41.2$ million from a possible $\$ 48.5$ million reward payment. The COAG Reform Council (2012) noted that the new target was "more ambitious" than the previous year. Queensland met eight literacy and numeracy targets, "made progress" towards seven, and failed to meet one. Again, the high stakes nature of NAPLAN data as a central lever in managing schools becomes clear, given that not only had Queensland made explicit efforts to redirect schooling towards NAPLAN improvement, but that despite this, Queensland had failed to meet all targets.

\section{My School, school choice and data}

The federal government's My School went live in January 2010, amidst opposition from teacher unions and educators, but widespread support from the Australian media (Lingard, 2010). Early news reports indicated that the site was popular amongst "frenzied" parents who began using the data to move their children away from "poor performing" schools (Lam, 2010). These kinds of 
reports serve as useful examples of how this newly-public data quickly began to bolster marketisation through moralistic and fear driven language (Davies \& Bansel, 2007, p. 251).

School choice may have been part of educational discourses in Australia for decades, but has intensified as schools have been formed as measurable and comparable commodities through the publication of NAPLAN data on $M y$ School. The push towards the marketisation of education is exemplified by a speech that the then-Prime Minister Julia Gillard gave when My School was launched. She declared that "you will see more information about Australia's near-10, 000 schools than you ever have before. For the first time, parents will be able to see exactly how their child's school is doing" (Gillard, 2010). Proponents of neoliberal policies commonly argue that competitive systems will correct inequity because in an open market schools become more effective and efficient, in order to compete for "customers".

Policies that allow schools to be viewed as "products" with comparable characteristics, ostensibly enable consumers (parents) to make informed decisions (Gillborn \& Youdell, 2000). Gillborn and Youdell (2000) note that for education to function as a market, it requires the fabrication of a level playing field where products have comparable characteristics, and consumers ostensibly make informed decisions. My School not only publishes NAPLAN results of each school, but also provides with comparisons against national benchmarks, national averages and statistically similar schools. ${ }^{4}$ The Index of Community Socio-Educational Advantage (ICSEA) uses variables such as household income, parental education and employment, remoteness and Indigeneity (ACARA, 2009), and is used to allow parents to compare "like with like". These comparisons are also intended to encourage underperforming schools to "learn lessons from high achieving schools" and to pull themselves up "by the bootstraps" (Comber \& Cormack, 2013, p. 80).

According to this logic, bolstering the education market is the solution to issues of inequity. Market-oriented logics link competition and choice with fairness and opportunity. Although equity is a part of neoliberal discourses, it is generally framed in terms of individual rights and responsibilities, for example, the right of parents/consumers to choose schools. Unfortunately, there is little evidence that education systems make any significant gains under such systems. A large body of literature over the past 40 years has repeatedly found that neoliberal education policy assemblages have increased inequalities in terms of education, income, wealth and privilege (e.g., Gillborn \& Youdell, 2000; Thomson, 2008). The harmful effects of school choice have been well-documented, and include the "residualisation" of underperforming schools as they are abandoned by parents with the social and economic capital to move their children to better performing schools (Kenway, 2013). Indeed, 2018 PISA data indicates that gap between the highest and lowest students in Australian schools is now greater than the OECD average (Thomson, De Bortoli, Underwood \& Schmid, 2019). 
Education funding and data

In 2010 the federal government commissioned a Review of Funding for Schooling widely known as Gonski (named after lead author David Gonski) that drew more than 7,000 submissions (Gonski et al., 2011). The commissioners' recommendation included that overall funding needed to be significantly increased; that the majority of funding increases should be directed towards government schools; that a "schooling resource standard" be created to determine school funding based on base funding with loadings for students with additional needs (e.g., Indigenous students, students from disadvantaged backgrounds and students with a disability). The review recommended that NAPLAN data be used to calculate this per student funding, and identified "reference schools" as being those that had the level of resources needed to achieve $80 \%$ of students at or above the national minimum standard in their year level for reading and numeracy from 2008 to 2010. Justman and Ryan (2013) have argued that the construction of the category reference schools is "flawed because it fails to control for the impact of student background on student achievement, confounding it with the contribution of the school itself to the achievement of its student body" (p. 6).

The Gonski report was produced during a period of political uncertainty (including a federal election cycle), and was shelved for more than 14 months, until weeks after the government of the day called a federal election. Having announced its new education policy in time for the election campaign, the federal government quickly began to strike funding agreements with state and territory governments based on their new model. Within ten days, New South Wales had reached an agreement worth $\$ 5$ billion extra funding over six years. In the months that followed, the National Catholic Education Commission, Independent Schools Council of Australia, and all states and territories except Queensland, Western Australia and the Northern Territory had reached agreements of their own.

After forming government, the new conservative Education Minister, Christopher Pyne announced in November that it was "back to the drawing board" for education policy (Wilson, 2013) and that funding agreements with states would be renegotiated over the coming year. Amid outcry from the states with existing agreements, Pyne announced that the government would allocate $\$ 230$ million in new funding for the states without agreements, with the intent that agreements be struck by December 2013. Those states that had not signed agreements prior to the coalition's victory found themselves in an entirely different position to those that had.

Since that time, Australia has continued to make heavy use of large-scale assessment data in education policy. The Alice Springs (Mparntwe) Education Declaration (2019) for example, devotes one of its 24 pages to outlining the importance of good quality data. Its first goal is that "The Australian education system promotes excellence and equity" (p. 5), which will no doubt require an ongoing commitment to the collection and use of large data sets that will serve 
as measures of both excellence and equity. The review of funding known as Gonski 2.0 (Gonski et al., 2018) referenced both PISA and NAPLAN data as justifications for further funding reform. For example, the report used NAPLAN data to describe up to $30 \%$ of Australian schools as "cruising". 5 In the introduction to an edited book entitled Flip the system: Changing education from the ground up written by teachers and education researchers, Netolicky, Andrews and Paterson (2019) have suggested that the language of cruising schools and teachers "smacks of a distrust of the teaching profession and deficit assumptions about current education practices" (p. 1). These discourses, they argue, value standardised data ahead of teachers' professional knowledge and judgement.

\section{NAPLAN reviews and NAPLAN online}

Despite the highest priority being afforded to improvement over the past decade, 2018 PISA data indicates a continued absolute ${ }^{6}$ decline in the reading and mathematics scores of 15-year-old Australian students. The raft of national goals to improve Australia's international standing on PISA, and policy reform aimed at literacy and numeracy improvement has instead been met with a deteriorating set of results that prompted federal Education Minister Dan Tehan to call for an intensified "back to basics" (Baker, 2019) approach to reform. The 2018 NAPLAN data was similarly disappointing with national scores across the majority of domains and year levels having moved little since testing commenced.

After a decade of NAPLAN testing, 2017 national longitudinal data also indicated mixed results. Statistically significant improvements were recorded in reading (Years 3 and 5), spelling (Years 3 and 5), grammar and punctuation (Year 3) and numeracy (Year 5), meaning that a large number of domains did not deliver anticipated improvements. There is a notable lack of improvement in Year 9. Worryingly for politicians, a statistically significant decline was recorded in writing (Year 7). Unsurprisingly, the media have continued to use NAPLAN as part of the national narrative around education, with headlines such as "Writing Wrongs: NAPLAN Shock" (English, 2019) and "NAPLAN: \$20bn flop, schools fail to lift most students' academic results” (Urban, 2019).

One of the early and ongoing concerns around NAPLAN was the reliability and validity of the data (Wu, 2010a). From its inception there were concerns around the misinterpretation and misuse of data as a basis for policy decision making (Wu, 2010b). Concerns about the usefulness of NAPLAN data have continued, most recently in relation to the moves to "NAPLAN Online". From 2018, schools could opt to take part in the online option. In 2019 more than half of schools across the country participated in the online format. Not only were there significant technical disruptions that meant large numbers of students were unable to complete tests, but there were also issues of validity and reliability when comparing the results of students who sat the online and traditional pen-and-paper tests. For example, students in Years 3 and 5 were disadvantaged by NAPLAN online in the spelling domain. 
Despite having been introduced as a means of improving equity for Australian students, long-term trend data indicates the opposite: in all domains, students whose parents hold a bachelor degree or higher have the highest mean scale scores. Similarly students whose parents work in professional jobs ${ }^{7}$ have the highest mean scale scores across all domains. Students in major cities also have the highest mean scale score, followed by students attending schools in inner regional areas, trailed by students in outer regional areas, then students in remote and very remote schools.

Providing something of a contrast to national trends, Queensland, the state where the research presented in this book was carried out, have enjoyed some of the strongest gains in NAPLAN data. As described above, Queensland's poor 2008 results resulted in something of a "wake-up call" that generated statistically significant improvements in the early years of implementation. For example Queensland was one of only two jurisdictions to record gains in Year 3 numeracy over the period 2008-2018. Queensland's introduction of an additional year of schooling ${ }^{8}$ during this period has been acknowledged as accounting for some of the positive gains (e.g., Dick, 2013). The following chapters provide an insight into the significant work that Queensland teachers have undertaken to bring about these gains. Their stories also highlight the costs and benefits of Australia's focus on NAPLAN.

The use of numbers in education policy is now so pervasive that they have "colonised our collective imagination" (Gorur, 2016, p. 1). Quantification allows aggregated data to be presented as a summation of education systems. As Australia's history shows, it also assumes that numbers can and should be used to make direct comparisons, judgments and to allocate funding and resources. What may have once seemed impossible (or at least improbable) has now become a common-sense: the Chief Statistician's (ABS, 1911) pronouncement that tabulating education statistics was too difficult and unnecessary given that the number of adults without literacy skills would be "very small and relatively insignificant" (p. 167) stands in stark contrast to contemporary views that see quantified data as a necessity for understanding the state of education.

\section{Book outline}

The book is presented in eight chapters. In it, I present the stories from the teachers and leaders at two schools as they work in a school system where large-scale standardised assessment data is pivotal to how their work is assessed, managed and understood. These stories are not intended to be exhaustive accounts. Instead, these individual stories are gathered together to show the convergence ruling relations.

My aim throughout is to explicate how data (including the multitude of policies that seek to quantify education) reorganises teachers' work at the local level, since teachers' work is "carried out at an intersection between ... globalising discourses, educational change, and ... local experiences with schooling" (Griffith \& André-Bechely, 2008, p. 42). I do not wish to draw conclusions about whether particular statistics are inherently "good or bad"; but rather, to problematise the quantification of education and to unpack the way in which the underlying ideological code is experienced at the local level. Smith (1993) 
describes an ideological code as "a schema that replicates its organisation in multiple and various sites ... [to] generate the same order in widely different settings of talk or writing - legislative, social scientific, popular writing, administrative, television advertising, and whatever" (pp. 51-52).

This chapter has provided a historical overview of the ascendancy of data in education. This history is the backdrop to contemporary taken-for-granted rationalities about the importance (and naturalness) of collecting education data. The chapter has also examined policy and media reports about data, standardised testing and teachers' work, as well as other grey literature that details how teachers themselves perceive the impact of data on their work. Contrasting these views has established the divide between how teachers experience data-driven (or datainformed) policy ensembles, and how these are seen from outside of schools. The following chapters shine a light on these divergent views by exploring teachers' perspectives, and making empirical links to education policy assemblages.

Chapter 2 outlines the research program presented in the book, and introduces the educators working who took part in the study. It also introduces institutional ethnography as the method of inquiry used to bring these power relations to light. I note here that Smith does not use the term "institution" to refer to a single organisation such as a school, or even an education department. Instead she uses the term to describe the "complex set of relations that form part of the ruling apparatus, normally organised around a specific function, such as education" (Smith, 1987, p. 160). The institution is used as an alternative to typical organisational forms such as bureaucracy because it makes room for the analysis of a range of different forms of organisation, from schools to government departments and large global organisations such as the OECD.

Chapter 3 sets the scene for the analytic chapters that follow by examining the policies around test administration, using Australia's NAPLAN assessment program as an illustrative example. The chapter provides examples of teachers' work on NAPLAN test days, before moving to explain how the tests are marked, assembled into reports and produced in a format that is ready for distribution back to schools, the media and families.

Chapter 4 focusses on understanding how NAPLAN data is linked to the performance management of schools and school principals. This chapter provides an account of the pressure on school principals to focus school operations around departmental and regional key performance indicators.

Chapter 5 explores how principals respond to the pressures and performance management discussed in the preceding chapter. It introduces the local policies principals adopted within their own schools, including mandating data cycles, changes in curriculum, pedagogy, school based assessment and resourcing.

Chapter 6 makes teachers' work with data - and in response to data - visible. The chapter contrasts the experiences of teachers at two of the schools. It picks up on the decisions principals made in response to school performance management, and discusses the implications of these decisions for teachers' work. For example, it looks at the impacts on the time teachers spend on activities 
such as additional in-class testing, as well as how and why they reorient their work towards the skills and knowledge in NAPLAN tests.

Chapter 7 maps how the institutional mandates described in the preceding chapter are taken up at the school level. An example from each of the two schools is used to trace how teachers' work is coordinated by sequences of texts that form what Smith and Turner (2014) describe as "institutional circuits" (p. 10). An example of the reorganisation of work is also provided, using a standardised test that was used at both schools, as a means of illustrating how teachers' work is coordinated in similar ways in different settings.

The final chapter brings together the evidence presented across the book to explain how teachers' work is linked to the operation of a series of texts that rely heavily on quantified education data. It summarises the impacts of data on teachers' work both in and out of the classroom, and returns to the disjuncture between how data is seen by those outside the system - such as the media and policy makers; and educators. The chapter concludes with some insights into possibilities for how data can be used in more productive ways that might ultimately lead to greater benefits for both educators and students.

\section{Notes}

1 In Australia, compulsory primary schooling begins when children are between fourand-a-half and five-and-a-half years of age. Children attend primary school until they are 11 or 12 years of age, after which they commence secondary schooling. Although systems differ across the states and territories, primary schools generally cover Foundation to Years 6 or 7, and secondary schools cover Years 7 or 8 to Year 12.

2 National Assessment Program -Literacy and Numeracy (NAPLAN).

3 www.mamamia.com.au/naplan-results-2019/

4 According to ACARA's website, a school's ICSEA value is used to select approximately 59 schools with students with similar socio-educational advantage (www.aca ra.edu.au/_resources/

Guide_to_understanding_2013_ICSEA_values.pdf). My School has also used the terms "like schools" and "similar schools".

5 The report describes these schools as “"cruising' from year to year rather than improving results between years at the same rate as similar schools. Cruising schools achieve outcomes above minimum standards, but deliver lower rates of learning growth than comparable schools" (p. 10).

6 Australia's 2018 PISA results indicate both an absolute and comparative decline.

7 ACARA uses the category "Occupation Group 1" to denote jobs including qualified professionals and senior managers.

8 "Prep" or the Preparatory year of schooling was introduced in Queensland in 2007, meaning the first Prep students to have completed did so in 2011.

\section{References}

Ainley, J. (2002). Assessment in primary schools. In T. Townsend (Ed.). The Primary School in Changing Times: The Australian experience (pp. 192-206). London, UK: Routledge. 


\section{Boom! And it's all about data}

Australian Bureau of Statistics (ABS). (1911). Census of the Commonwealth of Australia, 1911. Canberra, ACT: Commonwealth of Australia. Retrieved from www.abs. gov.au/AUSSTATS/abs@.nsf/DetailsPage/2112.01911?OpenDocument.

Australian Bureau of Statistics (ABS). (2001). Measuring Education In Australian Censuses-1911 to 2001. Retrieved from www.abs.gov.au/AUSSTATS/abs@.nsf/Pre viousproducts/1301.0Feature\%20Article242001?opendocument\&tabname=Summa ry\&prodno $=1301.0 \&$ issue $=2001 \&$ num $=\&$ view $=$.

Australian Curriculum Assessment and Reporting Authority (ACARA). (2008). Technical paper: Index of Community Socio-Educational Advantage (ICSEA). Sydney, NSW: Australian Government. Retrieved from http://members.webone.com.au/ $\sim$ markld/PubPol/HR/MySchoolICSEATECHNICALPAPER20091020.pdf.

Australian Education Council. (1989). The Hobart Declaration on Schooling. Canberra, ACT: Commonwealth of Australia. Retrieved from www.educationcouncil.edu.au/ EC-Publications/EC-Publications-archive/EC-The-Hobart-Declaration-on-School ing-1989.aspx.

Australian Senate Education and Employment Reference Committee. (2014). Effectiveness of the National Assessment Program - Literacy and Numeracy. Final Report. Canberra, ACT: The Australian Government. Retrieved from www.aph.gov.au/ParliamentaryBu siness/Committees/Senate/EducationandEmployment/Naplan13/Report/index.

Baker, J. (2019, December 7). Settling scores. The Sydney Morning Herald, Retrieved January 3, 2020 from Factiva.

Baroutsis, A., \& Lingard, B. (2019) Headlines and hashtags herald new 'damaging effects' in education policy? Media commentary on Australia's declining PISA performance. In A. Baroutsis, S. Riddle, and P. Thompson (Eds.), Education research and media (pp. 27-46). London, UK: Routledge.

Biesta, G. (2015). Resisting the seduction of the global education measurement industry: Notes on the social psychology of PISA. Ethics and Education, 10(3), 348-360.

Bita, N. (2013, December 4). PISA report finds Australian teenagers worse than 10 years ago. The Courier Mail, Retrieved January 3, 2020 from Factiva.

Bowker, G. C., \& Star, S. L. (1999). Sorting things out: Classification and its consequences. Cambridge, MA: MIT Press.

Callahan, R. B. (1962). Education and cult of efficiency. Chicago, IL: University of Chicago Press.

Campbell, M. (2003). Dorothy Smith and knowing the world we live in. Journal of Sociology and Social Welfare, 30(1), 3-22.

Chilcott, T. (2012a, February 18). Chaos in schools, warn teachers as Australian curriculum rolled out. The Courier Mail. Retrieved from www.couriermail.com.au/news/ queensland/chaos-in-schools-as-new-system-rolls-in/story-e6freoof-1226274286047.

Chilcott, T. (2012b, January 28). Report card: How your school stacks up. The Courier Mail. Retrieved from www.couriermail.com.au/archive/news/ report-card-ho w-your-school-stacks-up/story-fnbwroq7-1226255868681.

Christie, F. (1998). Benchmarking. Curriculum Perspectives, 18(3), 43-45.

Comber, B., \& Cormack, P. (2013). High-stakes literacy tests and local effects in a rural school. Australian Journal of Language and Literacy, 36(2), 78-89.

Commonwealth Grants Commission. (2012). 2012 Update: New issues for discussion paper: CGC 2011-18-S (September 2011). Retrieved from https://cgc.gov.au/index. php?option $=$ comcontent $\&$ view $=$ article $\&$ id $=231 \&$ Itemid $=322$.

Council of Australian Governments (COAG). (2008). National Partnership Agreement on Literacy and Numeracy. Retrieved from www.federalfinancialrelations.gov.au/ content/npa/education/smarterschools/literacynumeracy/nationalpartnership.pdf. 
Council of Australian Governments (COAG). (2009). Intergovernmental Agreement on Federal Financial Relations. Canberra, ACT. Retrieved from www.federalfinancia lrelations.gov.au/content/guidelines/Short-Guide-Intergovernmental-Agreement.pdf.

Council of Australian Governments(COAG). (2012). National Partnership Agreement on Literacy and Numeracy: Performance report for 2011. Sydney, NSW: COAG Reform Council. Retrieved from http://library.bsl.org.au/ jspui/bitstream/1/3451/1/Nationa 1PartnershiponLiteracyandNumeracyPerformanceReportfor201130April2012.pdf.

Council of Australian Governments Education Council. (2019). Alice Springs (Mparntwe) Education Declaration. Canberra, ACT. Retrieved from https://uploadstorage.blob. core.windows.net/public-assets/education-au/melbdec/ED19-0230\%20-\%20SCH\% 20-\%20Alice\%20Springs\%20(Mparntwe)\%20Education\%20Declaration_ACC.pdf.

Cumming, J. J., \& Mawdsley, R. D. (2012). The nationalisation of education in Australia and annexation of private schooling to public goals. International Journal of Law and Education, 17(2), 7-31.

Davies, B., \& Bansel, P. (2007). Neoliberalism and education. International Journal of Qualitative Studies in Education, 20(3), 247-259.

Department of Education, Training and Employment (DETE). (2011). United in our pursuit of excellence: Agenda for improvement 2012-2015. Brisbane, QLD: Queensland Government. Retrieved from http://education.qld.gov.au/ corporate/a bout/pdfs/united-in-our-pursuit-of-excellence.pdf.

Dick, C. (2013). Prep delivers for Queensland students in 2011 NAPLAN results. Media Statement. Brisbane, QLD: Queensland Government. Retrieved from http://statem ents.qld.gov.au/Statement/Id/76485.

Dworkin, A. G., \& Tobe, P. F. (2014). The effects of standards based school accountability on teacher burnout and trust relationships: A longitudinal analysis. In D. Van Maele, M. Van Houtte, \& P. B. Forsyth (Eds.), Trust and school life (pp. 121-143). Dordrecht, NL: Springer.

Education. (1918, December 16). The Telegraph, p. 6. Retrieved from http://trove.nla. gov.au/newspaper/article/179039390?searchTerm=educ...1\%20comparison\&sea rchLimits $=1$-category $=$ Article $\mid$ | | 1-availability $=\mathrm{y} \#$.

English, B. (2019, August 27). Writing wrongs: NAPLAN shock. Daily Telegraph Online, Retrieved January 7, 2020 from Factiva.

Ferrari, J. (2011, July 15). Teachers are "phobic" over student test data. The Australian, Retrieved from www.theaustralian.com.au/national-affairs/policy/teachers-phobi c-over-pupil-test-data/story-fn59nlz9-1226094892362.

Fidler, R. (2017). Why school teacher Gabbie Stroud loved and left her career. Conversations with Richard Fidler, Radio Broadcast - Friday 10 February 2017, 11:00am. Retrieved from www.abc.net.au/radio/programs/conversations/conversations-ga bbie-stroud-rpt/8240730.

Friedman, M. (2005, December 5). The promise of vouchers. The Wall Street Journal. Retrieved from www.wsj.com/articles/ SB113374845791113764.

Gallagher, J., \& Spina, N. (2019). Caught in the frontline: examining the introduction of a new national data collection system for students with disability in Australia. International Journal of Inclusive Education, 1-15.

Gill, M. (1998). Who set the benchmarks? Analysing the national literacy agenda. English in Australia, 121. Retrieved from www.aate.org.au/documents/item/477.

Gillard, J. (2010). A future fair for all - School funding in Australia - Address to Sydney Institute [Press release]. Retrieved from https://ministers.employment.gov.au/gillard/ future-fair-all-school-funding-australia-address-sydney-institute. 
Gillborn, D., \& Youdell, D. (2000). Rationing education: Policy, practice, reform and equity. Buckingham, UK: Open University Press.

Goldstein, D. (2019, December 3). 'It Just Isn't Working': PISA Test Scores Cast Doubt on U.S. Education Efforts. The New York Times, Retrieved January 3, 2020 from Factiva.

Goldstein, H. (2004). International comparisons of student attainment: Some issues arising from the PISA study. Assessment in Education: Principles, Policy E Practice, 11(3), 319-330.

Gonski, D., Boston, K., Greiner, K., Lawrence, C., Scales, B., \& Tannock, P. (2011). Review of funding for schooling-Final report. Canberra, ACT: Commonwealth of Australia. Retrieved fromhttps://docs.education.gov.au/system/files/doc/other/revie w-of-funding-for-schooling-final-report-dec-2011.pdf.

Gonski, D., Arcus, T., Boston, K., Gould, V., Johnson, W., O’Brien, L., \& Roberts, M. (2018). Through growth to achievement: The report of the Review to Achieve Educational Excellence in Australian Schools. Canberra, ACT: Commonwealth of Australia.

Gorur, R. (2016). The performative politics on NAPLAN and My School. In B. Lingard, G. Thompson, \& S. Sellar (Eds.), National testing in schools: An Australian assessment (pp. 30-43). New York, NY: Routledge.

Griffith, A. I., \& André-Bechely, L. (2008). Institutional technologies: Coordinating families and schools, bodies and texts. In M. DeVault (Ed.), People at work: Life, power and social inclusion in the New Economy (pp. 40-56). New York, NY: New York University Press.

Groch, S. (2019, December 3). PISA 2018: Australian school scores fall on the world stage. Canberra Times. Retrieved from www.canberratimes.com.au/story/6522117/wa ke-up-call-australian-school-scores-plummet-on-world-stage/.

Grosvenor, I., \& Roberts, S. (2009). Systems and subjects: Ordering, differentiating, and institutionalising the modern urban child. In M. Lawn (Ed.), The rise of data in education systems: Collection, visualisation and use (pp. 79-96). Oxford, UK: Symposium Books.

Hess, F. (2019, December 30). 10 Moments That Capture a Decade in Education, Forbes. Retrieved from www.forbes.com/sites/frederickhess/2020/12/30/10-mom ents-that-capture-a-decade-in-education/\#18f4d1917bd1.

Hunter, F. (2019, December 9). Education Minister pushes for 'back to basics' approach in schools. The Sydney Morning Herald Online. Retrieved January 9, 2020 from Factiva.

Jerrim, J. (2017). Why does Vietnam do so well in PISA? An example of why naive interpretation of international rankings is such a bad idea, University College London, Institute of Education Blog. Retrieved from https://ioelondonblog.wordpress.com/ 2017/07/19/why-does-vietnam-do-so-well-in-pisa-an-example-of-why-naive-interp retation-of-international-rankings-is-such-a-bad-idea/.

Justman, M., \& Ryan, C. (2013). What's wrong with the Gonski Report: Funding reform and student achievement?Melbourne Institute Policy Briefs Series. Melbourne, VIC: University of Melbourne. Retrieved from www.melbourneinstitute. com/downloads/policybriefsseries/pb2013n02.pdf.

Karmel, P. (1985). Quality of education in Australia: Report of the Review Committee. Canberra, ACT: Quality for Education Review Committee. Retrieved from http:// hdl.voced.edu.au/10707/23318.

Kennedy, T., O’Neill, L., \& Devenish, K. (2011). Independent review of Education Queensland's Curriculum into the Classroom program: Primary mathematics. 
Retrieved from www.backtofrontmaths.com.au/wp-content/uploads/2011/12/ Independent-Review-of-EQs-Curriculum-into-the-Classroom-program-primary-ma thematics1.pdf.

Kenway, J. (2013). Challenging inequality in Australian schools: Gonski and beyond. Discourse: Studies in the Cultural Politics of Education, 34(2), 286-308.

Kickert, W. (1993). Steering at a distance: A new paradigm of public governance in Dutch higher education. Governance, 8(1), 135-157.

Klein, N. (2008). The shock doctrine: The rise of disaster capitalism. New York, NY: Metropolitan Books.

Lam, M. (2010, January 31). My School launch leads to parent frenzy. The Australian. Retrieved from www.news.com.au/national/my-school-launch-leads-to-paren t-frenzy/story-e6frfkw9-1225825079749.

Landahl, J., \& Landahl, C. (2009). (Mis-) trust in numbers: Shape shifting and directions in the modern history of data in Swedish educational reform. In M. Lawn (Ed.), The rise of data in education systems: Collection, visualisation and use (pp. 57-78). Oxford, UK: Symposium Books.

Lawn, M. (2009). The rise of data in education. In M. Lawn (Ed.), The rise of data in education systems: Collection, visualisation and use (pp. 7-11). Oxford, UK: Symposium Books.

Leung, C. (1998). Benchmarking literacy assessment: A case of curriculum displacement? Curriculum Perspectives, 18(3), 50-55.

Lewis, S. (2014). The OECD, PISA and educational governance: A call to critical engagement. Discourse: Studies in the Cultural Politics of Education, 35(2), 1-11.

Lingard, B. (2010). Policy borrowing, policy learning: Testing times in Australian schools. Critical Studies in Education, 51(2), 129-147.

Lingard, B., \& Sellar, S. (2013). 'Catalyst data': Perverse systemic effects of audit and accountability in Australian schooling. Journal of Education Policy, 28(5), 634-656.

Lipman, P. (2016). Economic crisis, accountability, and the state's coercive assault on public education in the USA. In B. Lingard, W. Martino, \& G. Rezai-Rashti (Eds.), Testing regimes, accountabilities and education policies (pp. 19-35). New York, NY: Routledge.

Luke, A., \& Van Kraayenoord, C. E. (1998). Babies, bathwaters and benchmarks: Literacy assessment and curriculum reform. Curriculum Perspectives, 18(3), 55-62.

McEvoy, P. (Executive Producer). (2018, October 8). “2018 Teaching special”. In Q\&A [television broadcast]. ABC Television.

McKnight, A. (2015, October 28). Children 'victims' of Australia's standardised education system. Merimbula News Weekly. Retrieved January 2, 2020 from Factiva.

Margolis, K. (2016). To All My Teaching Buddies [Facebook post]. Retrieved from: www.facebook.com/kathy.margolis.7/posts/10208843143294643.

Masters, G. (2009). A shared challenge: Improving literacy, numeracy and science learning in Queensland primary schools. Brisbane, QLD: Queensland Government. Retrieved from http://education.qld.gov.au/mastersreview/ pdfs/final-report-ma sters.pdf.

Mockler N. (2019) Shifting the Frame: Representations of Early Career Teachers in the Australian Print Media. In A. Sullivan, B. Johnson, M. Simons (Eds.). Attracting and Keeping the Best Teachers. Professional Learning and Development in Schools and Higher Education, vol. 16. Singapore, SGP: Springer.

Morton, R. (2013, May 20). NAPLAN tests too hard for teachers. The Australian, Retrieved from www.theaustralian.com.au/national-affairs/policy/naplan-tests-too-ha rd-for-teachers/story-fn59nlz9-1226646349626. 


\section{Boom! And it's all about data}

Mourad, S. (2018, August 6) Trish Antulov's tragic death at work a blight on teaching. Daily Mail. Retrieved January 2, 2020 from Factiva.

Novoa, A. N., \& Yariv-Mashal, T. (2003). Comparative Research in Education: a mode of governance or a historical journey? Comparative Education, 39(4), 423-438.

Netolicky, D., Andrews, J., \& Paterson, C. (2019). Flip the system: Changing education from the ground up. New York, NY: Routledge.

Penberthy, D. (2019, December 15). Let's get back to basics, Hobart Mercury. Retrieved March 23, 2020 from Factiva.

Porter, T. M. (1996). Trust in numbers: The pursuit of objectivity in science and public life. Princeton, NJ: Princeton University Press.

Porter, T. M. (2012). Funny numbers. Culture Unbound, 4(4), 585-598.

Queensland Government. (2009). Annual Performance Report. Educational foundations: Numeracy and literacy. Retrieved from http://deta.qld.gov.au/ publica tions/annual-reports/08-09/performance-reports/foundations/ numeracy-literacy. html\#max.

Queensland Teachers' Union of Employees (QTU). (2012). C2C: Your professional choice. Members' Newsflash, 05(12). Retrieved from Queensland Teachers' Union website www.qtu.asn.au/files//3413/3003/9415/Nflash-05-12.pdf.

Rose, N. (2003). Powers of freedom: Reframing political thought (3rd ed.). Cambridge, UK: Cambridge University Press.

Rothman, S. (2002). Achievement in literacy and numeracy by Australian 14 year-olds, 1975-1998. Canberra, ACT: Australian Council for Educational Research. Retrieved from www.lsay.edu.au/publications/1862.html.

Rudd, K., \& Gillard, J. (2008). Quality Education: The case for an Education Revolution in our schools. Canberra, ACT: Commonwealth of Australia. Retrieved from http://apo. org.au/resource/quality-education-case-education-revolution-our-schools.

Sahlberg, P. (2007). Education policies for raising student learning: The Finnish approach. Journal of Education Policy, 22(2), 147-171.

Schleicher, A. (2013). Big data and PISA [Andreas Schleicher: Deputy Director and Special Advisor on Education Policy to the OECD's Secretary-General]. Retrieved from http://oecdeducationtoday.blogspot.com.au/2013/07/big-data-and-pisa.html.

Sellar, S., \& Lingard, B. (2013). Looking east: Shanghai, PISA 2009 and the reconstitution of reference societies in the global education policy field. Comparative Education, 49(4), 464-485.

Shannon, P., \& Edmondson, J. (1998). A look at educational benchmarking in the United States. Curriculum Perspectives, 18(3), 45-49.

Smith, D. E. (1974). Women's perspective as a radical critique of sociology. Sociological Inquiry, 44(1), 7-13.

Smith, D. E. (1987). The everyday world as problematic: A feminist sociology. Boston, MA: Northeastern University Press.

Smith, D. E. (1999). Writing the social: Critique, theory and investigations. Toronto, ON: University of Toronto Press.

Smith, D. E. (2003). Making sense of what people do: A sociological perspective. Journal of Occupational Science, 10(1), 61-64.

Smith, D. E., \& Turner, S. M. (Eds.). (2014). Incorporating texts into institutional ethnographies. Toronto, ON: University of Toronto Press.

Smith, W. (Ed.) (2016). The global testing culture: Shaping education policy, perceptions, and practice. Oxford, UK: Symposium Books. 
Sobe, N. W., \& Boven, D. T. (2014). Nineteenth-century world's fairs as accountability systems: Scopic systems, audit practices and educational data. Education Policy Analysis Archives, 22, 118.

Steering Committee for the Review of Commonwealth/State Service Commission. (1995). Report on Government Services. Melbourne, VIC: Commonwealth of Australia. Retrieved from www.pc.gov.au/research/ongoing/report-on-government-ser vices/1995/1995/1995.pdf.

Stevens, K. (2019, December 5). Revealed: The best and worst states for your children's education - as Australia's abysmal school report card shows we are three years behind China, The Daily Mail. Retrieved January 3, 2020 from Factiva.

Stroud, G. (2019). Teacher: One Woman's Struggle to Keep the Heart in Teaching. Crows Nest, NSW: Allen \& Unwin.

Stroud, G. J. (2016). Teaching Australia. Griffith Review, 51, Fixing the System. Retrieved from https://griffithreview.com/articles/teaching-australia/.

Thomson, P. (2008). Lessons for Australia?: Learning from England's curriculum 'black box'. English in Australia, 43(3), 13-20.

Thomson, S., De Bortoli, L., Underwood, C., Schmid, M. (2019). PISA 2018: Reporting Australia's Results. Volume I Student Performance. Camberwell, VIC: Australian Council for Educational Research. Retrieved fromhttps://research.acer.edu.au/ozpisa/35.

Twomey, A. (2014). Federal-state financial relations and the constitutional limits on spending public money. Sydney, NSW: University of Sydney. Retrieved from https://sydney. edu.au/law/cru/documents/2014/201403PublicMoney.pdf.

Urban, R. (2019, August 28). NAPLAN: \$20bn flop, schools fail to lift most students' academic results, The Australian. Retrieved from www.theaustralian.com.au/nation/ naplan-schools-fail-to-lift-kids-with-20bn-flop/news-story/ fc66de280d72b622080d3c8384961b10.

Willis, S. (1998). First do no harm: Accountability and the numeracy benchmarks. Curriculum Perspectives, 18(3), 70-77.

Wilson, L. (2013, November 25). Back to the drawing board for Gonski, says Christopher Pyne. The Australian. Retrieved from www.theaustralian.com.au/national-affa irs/education/back-to-drawing-board-for-gonski-says-christopher-pyne/ story-fn59nlz9-1226767435893.

Wu, M. (2010a). The inappropriate use of NAPLAN data. Professional Voice, 8(1), 21-26.

$\mathrm{Wu}, \mathrm{M}$. (2010b). Measurement, sampling, and equating errors in large-scale assessments. Educational Measurement: Issues \& Practice, 29(4), 15-27. 


\section{Notes}

\section{Chapter 1}

1 In Australia, compulsory primary schooling begins when children are between fourand-a-half and five-and-a-half years of age. Children attend primary school until they are 11 or 12 years of age, after which they commence secondary schooling. Although systems differ across the states and territories, primary schools generally cover Foundation to Years 6 or 7, and secondary schools cover Years 7 or 8 to Year 12.

2 National Assessment Program -Literacy and Numeracy (NAPLAN).

3 www.mamamia.com.au/naplan-results-2019/

4 According to ACARA's website, a school's ICSEA value is used to select approximately 59 schools with students with similar socio-educational advantage (www.aca ra.edu.au/_resources/

Guide_to_understanding_2013_ICSEA_values.pdf). My School has also used the terms "like schools" and "similar schools".

5 The report describes these schools as “"cruising' from year to year rather than improving results between years at the same rate as similar schools. Cruising schools achieve outcomes above minimum standards, but deliver lower rates of learning growth than comparable schools" (p. 10).

6 Australia's 2018 PISA results indicate both an absolute and comparative decline.

7 ACARA uses the category "Occupation Group 1" to denote jobs including qualified professionals and senior managers.

8 "Prep" or the Preparatory year of schooling was introduced in Queensland in 2007, meaning the first Prep students to have completed did so in 2011.

\section{Chapter 2}

1 Pseudonyms are used throughout for school names, as well as the names of individuals.

2 During the period of data collection, Year 7 was still undertaken in primary schools in Queensland. Students enrolling in Year 7 with minimal or no English were at school for approximately 12 weeks prior to Year 7 NAPLAN testing in May.

\section{Chapter 3}

1 This period Justin is referring to is known as the "test security period" (ACARA, 2019c) which includes protocols such as ensuring "spare or unused test books are not used as practice books for any students (regardless of year level) before the end of the 


\section{Notes}

test security period" (p. 27) and that "the content of the tests must not be disclosed prior to the scheduled tests or during the test security period" (p. 4).

2 This chapter follows the 2014 release of NAPLAN. The timeframes for data release have been collapsed since 2014 following the Senate Review recommendations which included a faster turnaround of results (Australian Senate Education and Employment Reference Committee, 2014, p. vii).

\section{Chapter 4}

1 The removal or exclusion of students from testing was not a policy or practice sanctioned by the Department of Education.

\section{Chapter 5}

1 U2B refers to students in the "upper two bands" of NAPLAN. See Chapter 4 for further discussion of $\mathrm{U} 2 \mathrm{~B}$.

2 Public school websites in Australia typically provide access to a range of school annual reports and school reviews. Publication of this data enables states to meet legislative requirements (Australian Education Act 2013, 77(2)(f)).

\section{Chapter 6}

1 For example, the National School Improvement Tool (ACER, 2012) includes domains such as "Analysis and discussion of data" and "An explicit improvement agenda" where discussion and use of data is given high priority.

\section{Chapter 7}

1 Reading running records were developed by distinguished New Zealand educator and researcher, Marie Clay (e.g., Clay, 1993, 2001). They were designed to help classroom teachers identify patterns in student reading behaviours, and are now used regularly by teachers in many education systems including the U.S.A., U.K., Australia, Canada and New Zealand. Running records are commonly used in the early years of schooling to assist teachers in providing early intervention.

2 A Year 7 teacher at Swinton subsequently confirmed that the placemats were also used in Year 7.

3 Teaching and Learning Audits in Queensland were replaced by School Reviews in 2015. 


\section{References}

Ainley, J. (2002). Assessment in primary schools. In T. Townsend (Ed.). The Primary School in Changing Times: The Australian experience (pp. 192-206). London, UK: Routledge.

Australian Bureau of Statistics (ABS). (1911). Census of the Commonwealth of Australia, 1911. Canberra, ACT: Commonwealth of Australia. Retrieved from www.abs. gov.au/AUSSTATS/abs@.nsf/DetailsPage/2112.01911?OpenDocument.

Australian Bureau of Statistics (ABS). (2001). Measuring Education In Australian Censuses-1911 to 2001. Retrieved from www.abs.gov.au/AUSSTATS/abs@.nsf/Pre viousproducts $/ 1301.0$ Feature\%20Article242001?opendocument\&tabname $=$ Summa ry\&prodno $=1301.0 \&$ issue $=2001 \&$ num $=$ \&view $=$.

Australian Curriculum Assessment and Reporting Authority (ACARA). (2008). Technical paper: Index of Community Socio-Educational Advantage (ICSEA). Sydney, NSW: Australian Government. Retrieved from http://members.webone.com.au/ $\sim$ markld/PubPol/HR/MySchoolICSEATECHNICALPAPER20091020.pdf.

Australian Education Council. (1989). The Hobart Declaration on Schooling. Canberra, ACT: Commonwealth of Australia. Retrieved from www.educationcouncil.edu.au/ EC-Publications/EC-Publications-archive/EC-The-Hobart-Declaration-on-School ing-1989.aspx.

Australian Senate Education and Employment Reference Committee. (2014). Effectiveness of the National Assessment Program - Literacy and Numeracy. Final Report. Canberra, ACT: The Australian Government. Retrieved from www.aph.gov.au/ParliamentaryBu siness/Committees/Senate/EducationandEmployment/Naplan13/Report/index.

Baker, J. (2019, December 7). Settling scores. The Sydney Morning Herald, Retrieved January 3, 2020 from Factiva.

Baroutsis, A., \& Lingard, B. (2019) Headlines and hashtags herald new 'damaging effects' in education policy? Media commentary on Australia's declining PISA performance. In A. Baroutsis, S. Riddle, and P. Thompson (Eds.), Education research and media (pp. 27-46). London, UK: Routledge.

Biesta, G. (2015). Resisting the seduction of the global education measurement industry: Notes on the social psychology of PISA. Ethics and Education, 10(3), 348-360.

Bita, N. (2013, December 4). PISA report finds Australian teenagers worse than 10 years ago. The Courier Mail, Retrieved January 3, 2020 from Factiva.

Bowker, G. C., \& Star, S. L. (1999). Sorting things out: Classification and its consequences. Cambridge, MA: MIT Press.

Callahan, R. B. (1962). Education and cult of efficiency. Chicago, IL: University of Chicago Press. 
Campbell, M. (2003). Dorothy Smith and knowing the world we live in. Journal of Sociology and Social Welfare, 30(1), 3-22.

Chilcott, T. (2012a, February 18). Chaos in schools, warn teachers as Australian curriculum rolled out. The Courier Mail. Retrieved from www.couriermail.com.au/news/ queensland/chaos-in-schools-as-new-system-rolls-in/story-e6freoof-1226274286047.

Chilcott, T. (2012b, January 28). Report card: How your school stacks up. The Courier Mail. Retrieved from www.couriermail.com.au/archive/news/ report-card-ho w-your-school-stacks-up/story-fnbwroq7-1226255868681.

Christie, F. (1998). Benchmarking. Curriculum Perspectives, 18(3), 43-45.

Comber, B., \& Cormack, P. (2013). High-stakes literacy tests and local effects in a rural school. Australian Journal of Language and Literacy, 36(2), 78-89.

Commonwealth Grants Commission. (2012). 2012 Update: New issues for discussion paper: CGC 2011-18-S (September 2011). Retrieved from https://cgc.gov.au/index. php?option $=$ comcontent $\&$ view $=$ article $\&$ id $=231 \&$ Itemid $=322$.

Council of Australian Governments (COAG). (2008). National Partnership Agreement on Literacy and Numeracy. Retrieved from www.federalfinancialrelations.gov.au/ content/npa/education/smarterschools/literacynumeracy/nationalpartnership.pdf.

Council of Australian Governments (COAG). (2009). Intergovernmental Agreement on Federal Financial Relations. Canberra, ACT. Retrieved from www.federalfinancia lrelations.gov.au/content/guidelines/Short-Guide-Intergovernmental-Agreement.pdf.

Council of Australian Governments(COAG). (2012). National Partnership Agreement on Literacy and Numeracy: Performance report for 2011. Sydney, NSW: COAG Reform Council. Retrieved from http://library.bsl.org.au/ jspui/bitstream/1/3451/1/Nationa 1PartnershiponLiteracyandNumeracyPerformanceReportfor201130April2012.pdf.

Council of Australian Governments Education Council. (2019). Alice Springs (Mparntwe) Education Declaration. Canberra, ACT. Retrieved from https://uploadstorage.blob. core.windows.net/public-assets/education-au/melbdec/ED19-0230\%20-\%20SCH\% 20-\%20Alice\%20Springs\%20(Mparntwe)\%20Education\%20Declaration_ACC.pdf.

Cumming, J. J., \& Mawdsley, R. D. (2012). The nationalisation of education in Australia and annexation of private schooling to public goals. International Journal of Law and Education, 17(2), 7-31.

Davies, B., \& Bansel, P. (2007). Neoliberalism and education. International Journal of Qualitative Studies in Education, 20(3), 247-259.

Department of Education, Training and Employment (DETE). (2011). United in our pursuit of excellence: Agenda for improvement 2012-2015. Brisbane, QLD: Queensland Government. Retrieved from http://education.qld.gov.au/ corporate/a bout/pdfs/united-in-our-pursuit-of-excellence.pdf.

Dick, C. (2013). Prep delivers for Queensland students in 2011 NAPLAN results. Media Statement. Brisbane, QLD: Queensland Government. Retrieved from http://statem ents.qld.gov.au/Statement/Id/76485.

Dworkin, A. G., \& Tobe, P. F. (2014). The effects of standards based school accountability on teacher burnout and trust relationships: A longitudinal analysis. In D. Van Maele, M. Van Houtte, \& P. B. Forsyth (Eds.), Trust and school life (pp. 121-143). Dordrecht, NL: Springer.

Education. (1918, December 16). The Telegraph, p. 6. Retrieved from http://trove.nla. gov.au/newspaper/article/179039390?searchTerm=educ...1\%20comparison\&sea rchLimits $=1$-category $=$ Article | | | 1 -availability $=\mathrm{y} \#$.

English, B. (2019, August 27). Writing wrongs: NAPLAN shock. Daily Telegraph Online, Retrieved January 7, 2020 from Factiva. 
Ferrari, J. (2011, July 15). Teachers are "phobic" over student test data. The Australian, Retrieved from www.theaustralian.com.au/national-affairs/policy/teachers-phobi c-over-pupil-test-data/story-fn59nlz9-1226094892362.

Fidler, R. (2017). Why school teacher Gabbie Stroud loved and left her career. Conversations with Richard Fidler, Radio Broadcast - Friday 10 February 2017, 11:00am. Retrieved from www.abc.net.au/radio/programs/conversations/conversations-ga bbie-stroud-rpt/8240730.

Friedman, M. (2005, December 5). The promise of vouchers. The Wall Street Journal. Retrieved from www.wsj.com/articles/ SB113374845791113764.

Gallagher, J., \& Spina, N. (2019). Caught in the frontline: examining the introduction of a new national data collection system for students with disability in Australia. International Journal of Inclusive Education, 1-15.

Gill, M. (1998). Who set the benchmarks? Analysing the national literacy agenda. English in Australia, 121. Retrieved from www.aate.org.au/documents/item/477.

Gillard, J. (2010). A future fair for all - School funding in Australia - Address to Sydney Institute [Press release]. Retrieved from https://ministers.employment.gov.au/gillard/ future-fair-all-school-funding-australia-address-sydney-institute.

Gillborn, D., \& Youdell, D. (2000). Rationing education: Policy, practice, reform and equity. Buckingham, UK: Open University Press.

Goldstein, D. (2019, December 3). 'It Just Isn't Working': PISA Test Scores Cast Doubt on U.S. Education Efforts. The New York Times, Retrieved January 3, 2020 from Factiva.

Goldstein, H. (2004). International comparisons of student attainment: Some issues arising from the PISA study. Assessment in Education: Principles, Policy \& Practice, 11(3), 319-330.

Gonski, D., Boston, K., Greiner, K., Lawrence, C., Scales, B., \& Tannock, P. (2011). Review of funding for schooling-Final report. Canberra, ACT: Commonwealth of Australia. Retrieved fromhttps://docs.education.gov.au/system/files/doc/other/revie w-of-funding-for-schooling-final-report-dec-2011.pdf.

Gonski, D., Arcus, T., Boston, K., Gould, V., Johnson, W., O’Brien, L., \& Roberts, M. (2018). Through growth to achievement: The report of the Review to Achieve Educational Excellence in Australian Schools. Canberra, ACT: Commonwealth of Australia.

Gorur, R. (2016). The performative politics on NAPLAN and My School. In B. Lingard, G. Thompson, \& S. Sellar (Eds.), National testing in schools: An Australian assessment (pp. 30-43). New York, NY: Routledge.

Griffith, A. I., \& André-Bechely, L. (2008). Institutional technologies: Coordinating families and schools, bodies and texts. In M. DeVault (Ed.), People at work: Life, power and social inclusion in the New Economy (pp. 40-56). New York, NY: New York University Press.

Groch, S. (2019, December 3). PISA 2018: Australian school scores fall on the world stage. Canberra Times. Retrieved from www.canberratimes.com.au/story/6522117/wa ke-up-call-australian-school-scores-plummet-on-world-stage/.

Grosvenor, I., \& Roberts, S. (2009). Systems and subjects: Ordering, differentiating, and institutionalising the modern urban child. In M. Lawn (Ed.), The rise of data in education systems: Collection, visualisation and use (pp. 79-96). Oxford, UK: Symposium Books.

Hess, F. (2019, December 30). 10 Moments That Capture a Decade in Education, Forbes. Retrieved from www.forbes.com/sites/frederickhess/2020/12/30/10-mom ents-that-capture-a-decade-in-education/\#18f4d1917bd1. 
Hunter, F. (2019, December 9). Education Minister pushes for 'back to basics' approach in schools. The Sydney Morning Herald Online. Retrieved January 9, 2020 from Factiva.

Jerrim, J. (2017). Why does Vietnam do so well in PISA? An example of why naïe interpretation of international rankings is such a bad idea, University College London, Institute of Education Blog. Retrieved from https://ioelondonblog.wordpress.com/ 2017/07/19/why-does-vietnam-do-so-well-in-pisa-an-example-of-why-naive-interp retation-of-international-rankings-is-such-a-bad-idea/.

Justman, M., \& Ryan, C. (2013). What's wrong with the Gonski Report: Funding reform and student achievement?Melbourne Institute Policy Briefs Series. Melbourne, VIC: University of Melbourne. Retrieved from www.melbourneinstitute. com/downloads/policybriefsseries/pb2013n02.pdf.

Karmel, P. (1985). Quality of education in Australia: Report of the Review Committee. Canberra, ACT: Quality for Education Review Committee. Retrieved from http:// hdl.voced.edu.au/10707/23318.

Kennedy, T., O’Neill, L., \& Devenish, K. (2011). Independent review of Education Queensland's Curriculum into the Classroom program: Primary mathematics. Retrieved from www.backtofrontmaths.com.au/wp-content/uploads/2011/12/ Independent-Review-of-EQs-Curriculum-into-the-Classroom-program-primary-ma thematics1.pdf.

Kenway, J. (2013). Challenging inequality in Australian schools: Gonski and beyond. Discourse: Studies in the Cultural Politics of Education, 34(2), 286-308.

Kickert, W. (1993). Steering at a distance: A new paradigm of public governance in Dutch higher education. Governance, 8(1), 135-157.

Klein, N. (2008). The shock doctrine: The rise of disaster capitalism. New York, NY: Metropolitan Books.

Lam, M. (2010, January 31). My School launch leads to parent frenzy. The Australian. Retrieved from www.news.com.au/national/my-school-launch-leads-to-paren t-frenzy/story-e6frfkw9-1225825079749.

Landahl, J., \& Landahl, C. (2009). (Mis-) trust in numbers: Shape shifting and directions in the modern history of data in Swedish educational reform. In M. Lawn (Ed.), The rise of data in education systems: Collection, visualisation and use (pp. 57-78). Oxford, UK: Symposium Books.

Lawn, M. (2009). The rise of data in education. In M. Lawn (Ed.), The rise of data in education systems: Collection, visualisation and use (pp. 7-11). Oxford, UK: Symposium Books.

Leung, C. (1998). Benchmarking literacy assessment: A case of curriculum displacement? Curriculum Perspectives, 18(3), 50-55.

Lewis, S. (2014). The OECD, PISA and educational governance: A call to critical engagement. Discourse: Studies in the Cultural Politics of Education, 35(2), 1-11.

Lingard, B. (2010). Policy borrowing, policy learning: Testing times in Australian schools. Critical Studies in Education, 51(2), 129-147.

Lingard, B., \& Sellar, S. (2013). 'Catalyst data': Perverse systemic effects of audit and accountability in Australian schooling. Journal of Education Policy, 28(5), 634-656.

Lipman, P. (2016). Economic crisis, accountability, and the state's coercive assault on public education in the USA. In B. Lingard, W. Martino, \& G. Rezai-Rashti (Eds.), Testing regimes, accountabilities and education policies (pp. 19-35). New York, NY: Routledge.

Luke, A., \& Van Kraayenoord, C. E. (1998). Babies, bathwaters and benchmarks: Literacy assessment and curriculum reform. Curriculum Perspectives, 18(3), 55-62. 
McEvoy, P. (Executive Producer). (2018, October 8). "2018 Teaching special”. In Q\&A [television broadcast]. ABC Television.

McKnight, A. (2015, October 28). Children 'victims' of Australia's standardised education system. Merimbula News Weekly. Retrieved January 2, 2020 from Factiva.

Margolis, K. (2016). To All My Teaching Buddies [Facebook post]. Retrieved from: www.facebook.com/kathy.margolis.7/posts/10208843143294643.

Masters, G. (2009). A shared challenge: Improving literacy, numeracy and science learning in Queensland primary schools. Brisbane, QLD: Queensland Government. Retrieved from http://education.qld.gov.au/mastersreview/ pdfs/final-report-ma sters.pdf.

Mockler N. (2019) Shifting the Frame: Representations of Early Career Teachers in the Australian Print Media. In A. Sullivan, B. Johnson, M. Simons (Eds.). Attracting and Keeping the Best Teachers. Professional Learning and Development in Schools and Higher Education, vol. 16. Singapore, SGP: Springer.

Morton, R. (2013, May 20). NAPLAN tests too hard for teachers. The Australian, Retrieved from www.theaustralian.com.au/national-affairs/policy/naplan-tests-too-ha rd-for-teachers/story-fn59nlz9-1226646349626.

Mourad, S. (2018, August 6) Trish Antulov's tragic death at work a blight on teaching. Daily Mail. Retrieved January 2, 2020 from Factiva.

Novoa, A. N., \& Yariv-Mashal, T. (2003). Comparative Research in Education: a mode of governance or a historical journey? Comparative Education, 39(4), 423-438.

Netolicky, D., Andrews, J., \& Paterson, C. (2019). Flip the system: Changing education from the ground up. New York, NY: Routledge.

Penberthy, D. (2019, December 15). Let's get back to basics, Hobart Mercury. Retrieved March 23, 2020 from Factiva.

Porter, T. M. (1996). Trust in numbers: The pursuit of objectivity in science and public life. Princeton, NJ: Princeton University Press.

Porter, T. M. (2012). Funny numbers. Culture Unbound, 4(4), 585-598.

Queensland Government. (2009). Annual Performance Report. Educational foundations: Numeracy and literacy. Retrieved from http://deta.qld.gov.au/ publica tions/annual-reports/08-09/performance-reports/foundations/ numeracy-literacy. html\#max.

Queensland Teachers' Union of Employees (QTU). (2012). C2C: Your professional choice. Members' Newsflash, 05(12). Retrieved from Queensland Teachers' Union website www.qtu.asn.au/files//3413/3003/9415/Nflash-05-12.pdf.

Rose, N. (2003). Powers of freedom: Reframing political thought (3rd ed.). Cambridge, UK: Cambridge University Press.

Rothman, S. (2002). Achievement in literacy and numeracy by Australian 14 year-olds, 1975-1998. Canberra, ACT: Australian Council for Educational Research. Retrieved from www.lsay.edu.au/publications/1862.html.

Rudd, K., \& Gillard, J. (2008). Quality Education: The case for an Education Revolution in our schools. Canberra, ACT: Commonwealth of Australia. Retrieved from http://apo. org.au/resource/quality-education-case-education-revolution-our-schools.

Sahlberg, P. (2007). Education policies for raising student learning: The Finnish approach. Journal of Education Policy, 22(2), 147-171.

Schleicher, A. (2013). Big data and PISA [Andreas Schleicher: Deputy Director and Special Advisor on Education Policy to the OECD's Secretary-General]. Retrieved from http://oecdeducationtoday.blogspot.com.au/2013/07/big-data-and-pisa.html. 
Sellar, S., \& Lingard, B. (2013). Looking east: Shanghai, PISA 2009 and the reconstitution of reference societies in the global education policy field. Comparative Education, 49(4), 464-485.

Shannon, P., \& Edmondson, J. (1998). A look at educational benchmarking in the United States. Curriculum Perspectives, 18(3), 45-49.

Smith, D. E. (1974). Women's perspective as a radical critique of sociology. Sociological Inquiry, 44(1), 7-13.

Smith, D. E. (1987). The everyday world as problematic: A feminist sociology. Boston, MA: Northeastern University Press.

Smith, D. E. (1999). Writing the social: Critique, theory and investigations. Toronto, ON: University of Toronto Press.

Smith, D. E. (2003). Making sense of what people do: A sociological perspective. Journal of Occupational Science, 10(1), 61-64.

Smith, D. E., \& Turner, S. M. (Eds.). (2014). Incorporating texts into institutional ethnographies. Toronto, ON: University of Toronto Press.

Smith, W. (Ed.) (2016). The global testing culture: Shaping education policy, perceptions, and practice. Oxford, UK: Symposium Books.

Sobe, N. W., \& Boven, D. T. (2014). Nineteenth-century world's fairs as accountability systems: Scopic systems, audit practices and educational data. Education Policy Analysis Archives, 22, 118.

Steering Committee for the Review of Commonwealth/State Service Commission. (1995). Report on Government Services. Melbourne, VIC: Commonwealth of Australia. Retrieved from www.pc.gov.au/research/ongoing/report-on-government-ser vices/1995/1995/1995.pdf.

Stevens, K. (2019, December 5). Revealed: The best and worst states for your children's education - as Australia's abysmal school report card shows we are three years behind China, The Daily Mail. Retrieved January 3, 2020 from Factiva.

Stroud, G. (2019). Teacher: One Woman's Struggle to Keep the Heart in Teaching. Crows Nest, NSW: Allen \& Unwin.

Stroud, G. J. (2016). Teaching Australia. Griffith Review, 51, Fixing the System. Retrieved from https://griffithreview.com/articles/teaching-australia/.

Thomson, P. (2008). Lessons for Australia?: Learning from England's curriculum 'black box'. English in Australia, 43(3), 13-20.

Thomson, S., De Bortoli, L., Underwood, C., Schmid, M. (2019). PISA 2018: Reporting Australia's Results. Volume I Student Performance. Camberwell, VIC: Australian Council for Educational Research. Retrieved fromhttps://research.acer.edu.au/ozpisa/35.

Twomey, A. (2014). Federal-state financial relations and the constitutional limits on spending public money. Sydney, NSW: University of Sydney. Retrieved from https://sydney. edu.au/law/cru/documents/2014/201403PublicMoney.pdf.

Urban, R. (2019, August 28). NAPLAN: \$20bn flop, schools fail to lift most students' academic results, The Australian. Retrieved from www.theaustralian.com.au/nation/ naplan-schools-fail-to-lift-kids-with-20bn-flop/news-story/ fc66de280d72b622080d3c8384961b10.

Willis, S. (1998). First do no harm: Accountability and the numeracy benchmarks. Curriculum Perspectives, 18(3), 70-77.

Wilson, L. (2013, November 25). Back to the drawing board for Gonski, says Christopher Pyne. The Australian. Retrieved from www.theaustralian.com.au/national-affa irs/education/back-to-drawing-board-for-gonski-says-christopher-pyne/ story-fn59nlz9-1226767435893. 
Wu, M. (2010a). The inappropriate use of NAPLAN data. Professional Voice, 8(1), 21-26.

$\mathrm{Wu}$, M. (2010b). Measurement, sampling, and equating errors in large-scale assessments. Educational Measurement: Issues \& Practice, 29(4), 15-27.

André-Bechely, L. (2005). Could it be otherwise? Parents and the inequities of public school choice. New York, NY: Routledge.

Ball, S. J. (2012). Global education inc.: New policy networks and the neoliberal imaginary. Oxford, UK: Routledge.

Boudett, K. P., \& Steele, J. L. (2007). Data wise in action: Stories of schools using data to improve teaching and learning. Cambridge, MA: Harvard University Press.

Camargo, A. P. (2009). Sociology of statistics: Possibilities of a new field of investigation. História, ciências, saúde - manguinhos, 16(4), 903-926.

Campbell, M. (2003). Dorothy Smith and knowing the world we live in. Journal of Sociology and Social Welfare, XXX(1), 3-22.

Campbell, M., \& Gregor, F. (2002). Mapping social relations: A primer in doing institutional ethnography. Lanham, MD: AltaMira Press.

Cohen, P. C. (1982). A calculating people: The spread of numeracy in early America. New York, NY: Routledge.

Comber, B. (2012). Mandated literacy assessment and the reorganisation of teachers' work: Federal policy, local effects. Critical Studies in Education, 53(2), 119-136.

Comber, B., \& Cormack, P. (2013). High-stakes literacy tests and local effects in a rural school. Australian Journal of Language and Literacy, 36(2), 78-89.

Desrosières, A. (1998). The politics of large numbers: A history of statistical reasoning (C. Naish, Trans.). Cambridge, MA: Harvard University Press.

Desrosières, A. (2001). How real are statistics? Four possible attitudes. Social Research, 68 (2), 339-355.

DeVault, M. (Ed.) (2008). People at work: Life power and social inclusion in the New Economy. New York, NY: New York University Press.

Deveau, J. L. (2008). Examining the institutional ethnographer's toolkit. Socialist Studies, 4(2), 1-19.

Doherty, C. (2015). Making trouble: Ethnographic designs on ruling relations for students and teachers in non-academic pathways. The Australian Educational Researcher, 42(3), 353-370.

Domenech, D., Guidera, A. R., Edwards, M., \& Krueger, K. (2014). From accountability to informing instruction: The real power of data. Paper presented at the American Association of School Administrators, Nashville, TN. http://resources.aasa.org/Con ferenceDaily/CDO-presentations/2014/Feb13-1000-Informing-Instruction.pdf.

Ehrich, L. C., Harris, J., Klenowski, V., Smeed, J., \& Spina, N. (2015). The centrality of ethical leadership. Journal of Educational Administration, 53(2), 197-214.

Foucault, M. (1970). The order of things: An archeology of the human sciences. New York, NY: Vintage Books.

Griffith, A. I., \& André-Bechely, L. (2008). Institutional technologies: Coordinating families and schools, bodies and texts. In M. DeVault (Ed.), People at work: Life, power and social inclusion in the New Economy. New York, NY: New York University Press.

Grosvenor, I., \& Roberts, S. (2009). Systems and subjects: Ordering, differentiating, and institutionalising the modern urban child. In M. Lawn (Ed.), The rise of data in education systems: Collection, visualisation and use (pp. 79-96). Oxford, UK: Symposium Books.

Hacking, I. (1991). How should we do the history of statistics? In G. Burchell, C. Gordon, \& P. Miller (Eds.), The Foucault effect: Studies in governmentality (pp. 181195). Chicago, IL: University of Chicago Press. 
Hacking, I. (2006). Making up people. London Review of Books, 28(16-17), 23-26.

Harris, J., Carrington, S., \& Ainscow, M. (2017). Promoting equity in schools: Collaboration, inquiry and ethical leadership. New York, NY: Routledge.

Hovland, J. (2011). Numbers: Their relation to power and organisation. In A. R. Sætnan, H. M. Lomell, \& S. Hammer (Eds.), The mutual construction of statistics in society (Vol. 2, pp. 21-40). New York, NY: Taylor \& Francis.

Kerr, L. (2006). Between caring and counting: Teachers take on educational reform. Toronto, ON: University of Toronto Press.

Larner, W. (2003). Neoliberalism? Environment and Planning D: Society and Space, 21(5), 509-512.

Latour, B. (1999). Pandora's hope: Essays in the reality of science studies. Cambridge, MA: Harvard University Press.

McCoy, L. (2006). Keeping the institution in view: Working with interview accounts of everyday experience. In D. E. Smith (Ed.), Institutional ethnography as practice (pp. 109-126). New York, NY: Rowman \& Littlefield.

Miller, P. (1994). Accounting and objectivity: The invention of calculating selves and calculable spaces. In A. Megill (Ed.), Rethinking objectivity (pp. 239-264). London, UK: Duke University Press.

Nichols, N., \& Griffith, A. I. (2009). Talk, text, and educational action: An institutional ethnography of policy in practice. Cambridge Journal of Education, 39(2), 241-255.

Parkinson, H. C., \& Stooke, R. (2012). Other duties as assigned: The hidden work of reading and writing assessments in two primary classrooms. Language and Literacy, 14 (1), 585-598.

Pence, E. (2001). Safety for battered women in textually-mediated legal systems. Studies in Cultures, Organisations and Societies, 7, 199-229.

Pierce, D. (2014). Experts: Here's how to turn data into achievement. Retrieved from www.eschoolnews.com/2014/02/13/data-into-achievement-117/.

Porter, T. M. (1996). Trust in numbers: The pursuit of objectivity in science and public life. Princeton, NJ: Princeton University Press.

Porter, T. M. (2012). Funny numbers. Culture Unbound, 4(4), 585-598.

Rankin, J. M., \& Campbell, M. (2009). Institutional ethnography (IE), nursing work and hospital reform: IE's cautionary analysis. Forum: Qualitative Social Research, 10(2), Article 8. Retrieved from www.qualitative-research.net/index.php/fqs/article/view/1258/2720.

Rankin, J. M. (2014). The rhetoric of patient and family-centred care: An institutional ethnography into what actually happens. Journal of Advanced Nursing, 71(3), 526-534.

Rose, N. (1991). Governing by numbers: Figuring out democracy. Accounting, Organisation and Society, 16(7), 673-692.

Smith, D. E. (1974). Women's perspective as a radical critique of sociology. Sociological inquiry, 44(1), 7-13.

Smith, D. E. (1987). The everyday world as problematic: A feminist sociology. Boston, MA: Northeastern University Press.

Smith, D. E. (1990a). The conceptual practices of power: A feminist sociology of knowledge. Toronto, ON: University of Toronto Press.

Smith, D. E. (1990b). Texts, facts and femininity: Exploring the relations of ruling. London, UK: Routledge.

Smith, D. E. (1992). Sociology from women's experience: A reaffirmation. Sociological Theory, 10(1), 88-98.

Smith, D. E. (1996). The relations of ruling: A feminist inquiry. Studies in Cultures, Organisations and Societies, 2(2), 171-190. 
Smith, D. E. (1997). Comment on Hekman's 'Truth and method: Feminist standpoint theory revisited'. Signs, 22(2), (Winter), pp. 392-398.

Smith, D. E. (1999). Writing the social: Critique, theory and investigations. Toronto, ON: University of Toronto Press.

Smith, D. E. (2001). Texts and the ontology of organisations and institutions. Studies in Cultures, Organisations and Societies, 7(2), 159-198.

Smith, D. E. (2003). Making sense of what people do: A sociological perspective. Journal of Occupational Science, 10(1), 61-64.

Smith, D. E. (2004). Women's perspective as a radical critique of sociology. In S. Harding (Ed.), The feminist standpoint theory reader: Intellectual and political controversies (pp. 21-34). London, UK: Routledge.

Smith, D. E. (2005). Institutional ethnography: A sociology for people. Oxford, UK: Rowman Altamira.

Smith, D. E. (Ed.) (2006). Institutional ethnography as practice. New York, NY: Rowman \& Littlefield.

Apple, M. W. (2006). Understanding and interrupting neoliberalism and neoconservatism in education. Pedagogies: An International Journal, 1(1), 21-26.

Australian Curriculum Assessment and Reporting Authority (ACARA). (2019a). NAPLAN Handbook for Principals. 2019. Retrieved from www.nap.edu.au/verve/ resources/Nationalprotocolsfortestadministration2015-webversion.PDF.

Australian Curriculum Assessment and Reporting Authority (ACARA). (2019b). NAPLAN Test Administration Handbook for Teachers. Australian Curriculum Assessment and Reporting Authority (ACARA). Retrieved from www.qcaa.qld.edu.au/downloa ds/p_10/naplan_2019_admin_handbook_year3.pdf.

Australian Curriculum Assessment and Reporting Authority (ACARA). (2019c). National Protocols for Test Administration. Retrieved from www.nap.edu.au/napla $\mathrm{n}$ /school-support/national-protocols-for-test-administration.

Australian Curriculum Assessment and Reporting Authority (ACARA). (2014). NAPLAN 2014 Achievement in reading, persuasive writing, language conventions and numeracy. National report. Sydney, NSW. Retrieved from www.nap.edu.au/_ resources/National_Assessment_Program_Literacy_and_Numeracy_national_report_ for_2014.pdf.

Australian Senate Education and Employment Reference Committee. (2014). Effectiveness of the National Assessment Program - Literacy and Numeracy. Final Report. Canberra, ACT: The Australian Government. Retrieved from www.aph.gov.au/Pa rliamentaryBusiness/Committees/Senate/EducationandEmployment/Naplan13/Rep ort/index.

Ball, S. J. (2003). The teacher's soul and the terrors of performativity. Journal of Education Policy, 18(2), 215-228.

Bantick, C. (2014, May 4). Why I am a NAPLAN cheat. The Age. Retrieved from www. theage.com.au/national/education/why-i-am-a-naplan-cheat-20140501-zr2b4.html.

Baroutsis, A. (2016). Media accounts of school performance: Reinforcing dominant practices of accountability. Journal of Education Policy, 31(5), 567-582.

Barrett, R. (2014, May 3). NAPLAN coaching does not improve students' results in tests, ACARA chief says. ABC News Online. Retrieved from www.abc.net.au/news/ 2014-05-03/excessive-naplan-coaching-doesn't-improve-results/5427950.

Bess, M. (1988). Foucault interview: Power, morals and the intellectual. History of the Present, 4(1-2), 11-13. Retrieved from www.michaelbess.org/foucault-interview/. 
Calligeros, M. (2014, May 23). Queensland schools accused of NAPLAN cheating. The Brisbane Times. Retrieved from www.brisbanetimes.com.au/queensland/queensla nd-schools-accused-of-naplan-cheating-20140522-zrlnd.html.

Comber, B. (2012). Mandated literacy assessment and the reorganisation of teachers' work: Federal policy, local effects. Critical Studies in Education, 53(2), 119-136.

Creagh, S. (2014). A critical analysis of problems with the LBOTE category on the NAPLAN test. The Australian Educational Researcher, 41(1), 1-23.

Desrosières, A. (2011). Words and numbers: For a sociology of the statistical argument. In A. R. Sætnan, H. M. Lomell, \& S. Hammer (Eds.), The mutual construction of statistics in society (vol. 2, pp. 41-63). New York, NY: Routledge.

Dodd, T. (2014, August 18). More kids fail in maths and literacy. Australian Financial Review, Retrieved from www.afr.com/news/policy/education/more-kids-fail-in-ma ths-and-literacy-20140817-j8hlo.

Don't write off NAPLAN tests. (2014, August 19). The Australian. Retrieved from www.theaustralian.com.au/opinion/editorials/dont-write-off-naplan-tests/ story-e6frg71x-1227028599990.

Dore, C. (2014, August 18). Editorial: NAPLAN passing test for better outcomes. The Courier Mail. Retrieved from www.couriermail.com.au/news/opinion/editorial-napla n-passing-test-for-better-outcomes/story-fnihsr9v-1227028618498.

Ferrari, J. (2014a, May 12). Busting the NAPLAN myths. The Australian. Retrieved from www.theaustralian.com.au/news/features/busting-the-naplan-myths/ story-e6frg6z6-1226913710635.

Ferrari, J. (2014b, August 18). Marked down: How one tough question skewed NAPLAN results. The Australian. Retrieved from www.theaustralian.com.au/national $\% \mathrm{C} 2 \%$ ADaffairs/education/marked\%C2\%ADdown\%C2\%ADhow\%C2\%ADone\% C2\%ADtough\%C2\%ADquestion\%C2\%ADskewed\%C2\%ADthe\%C2\%ADnaplan\% C2\%ADresults/story\%C2\%ADfn59nlz9\%C2\%AD1227027488936.

Fleming, P., \& Porter, T. (2004). Life on the bell curve: An interview with Theodore Porter. Cabinet, 15(Fall). Retrieved from http://cabinetmagazine.org/issues/ 15/fleming2.php.

Ford, M. (2013). Achievement gaps in Australia: what NAPLAN reveals about education inequality in Australia. Australia, Race Ethnicity and Education, 16(1), 80-102.

Foucault, M. (1969/2002). The archeology of knowledge (A. Sheridan-Smith, Trans.). New York, NY: Harper \& Rowe.

Foucault, M. (1975/1995). Discipline and punish: The birth of the prison (A. Sheridan, Trans.). New York, NY: Vintage Books.

Foucault, M. (1997a). The birth of biopolitics. In P. Rabinow (Ed.), Michele Foucault: Ethics, subjectivity and truth (pp. 73-79). New York, NY: New York Press.

Foucault, M. (1997b). Ethics: Subjectivity and truth (R. Hurley, Trans. Vol. 1). New York, NY: St. Martin's Press.

Gibson, J. W. (1986). The perfect war: Technowar in Vietnam. New York, NY: Atlantic Monthly Press.

Gillborn, D. (2008). Conspiracy? Racism and education: Understanding race inequality in education. New York, NY: Routledge.

Griffith, A. I., \& Smith, D. E. (Eds.). (2014). Under new public management: Institutional ethnographies of changing front line work. Toronto, ON: University of Toronto Press.

Hacking, I. (1990). The taming of chance. Cambridge, UK: Cambridge University Press.

Hacking, I. (1991). How should we do the history of statistics? In G. Burchell, C. Gordon, \& P. Miller (Eds.), The Foucault effect: Studies in governmentality (pp. 181195). Chicago, IL: University of Chicago Press. 
Haggerty, K. D. (2001). Making crime count. Toronto, ON: University of Toronto Press. Jarvie, J. (2015, April 1). Atlanta schools cheating scandal: 11 educators convicted of racketeering. LA Times. Retrieved from www.latimes.com/nation/la-na-atlanta-school-chea ting-convictions-20150401-story.html-page $=1$.

Jensen, B. (2013, October 16). Writing on the wall for NAPLAN nay-sayers: We must improve results. The Australian. Retrieved from www.theaustralian.com.au/national-a ffairs/opinion/writing-on-the-wall-for-naplan-nay-sayers-we-must-improve-literacy/ story-e6frgd0x-1226740543880.

Jorland, G., Weisz, G., \& Opinel, A. (Eds.) (2005). Body counts: Medical quantification in historical and sociological perspectives. Montreal, QC: McGill-Queen's Press.

Latour, B. (1987). Science in action: How to follow scientists and engineers through society. Cambridge, MA: Harvard University Press.

Latour, B. (1988). The pasteurisation of France (A. Sheridan \& J. Law, Trans.). Cambridge, MA: Harvard University Press.

Lomell, H. M. (2011). Making sense of numbers: The presentation of crime statistics in the Oslo Police Annual Reports 1950-2008. In A. R. Sætnan, H. M. Lomell, \& S. Hammer (Eds.), The mutual construction of statistics in society (Vol. 2, pp. 191-206). New York, NY: Routledge.

Luke, A., Cazden, C., Coopes, R., Klenowski, V., Ladwig, J., Lester, J., MacDonald, S., Phillips, J., Shield, P. G., Spina, N., Theroux, P., Tones, M. J., Villegas, M., \& Woods, A. (2013). A summative evaluation of the Stronger Smarter Learning Communities Project. Brisbane, QLD: Queensland University of Technology. Retrieved fromhttp://eprints.qut.edu.au/59535/.

McDougall, B. (2014, March 27). Crackdown on National Assessment Program Literacy and Numeracy classroom cheats. The Australian. Retrieved from www.news.com.au/ national/crackdown?on?national?assessment?program?literacy?and?numeracy?cla ssroom?cheats/story?fncynjr2?1226865878298.

McGaw, B., Louden, W., \& Wyatt-Smith, C. (2019). NAPLAN Review Interim Report. Retrieved from https://education.nsw.gov.au/about-us/strategies-and-reports/our-rep orts-and-reviews/naplan-review/NAPLAN-Review-Interim-Report.pdf.

Porter, T. M. (2012). Funny numbers. Culture Unbound, 4(4), 585-598. Retrieved from www.cultureunbound.ep.liu.se/v4/a32/cu12v4a32.pdf.

Queensland Curriculum and Assessment Authority (QCAA). (2014). NAPLAN 14. Newsletter: July 2014. Brisbane, QLD. Retrieved from www.qcaa.qld. edu.au/down loads/p10/naplan14jul14.pdf.

Randall, R. (2014). Bringing NAPLAN home: The results and your child. Retrieved from ACARA website: www.acara.edu.au/verve/resources/20140723 NAPLANlet tertoparents.pdf.

Rankin, J. M., \& Campbell, M. (2006). Managing to nurse: Inside Canada's health care reform. Toronto, ON: University of Toronto Press.

Smith, D. E. (2006). Incorporating texts into institutional ethnography. In D. E. Smith (Ed.), Institutional ethnography as practice. New York, NY: Rowman \& Littlefield.

Smith, D. E. (2008). Institutional ethnography. In L. M. Given (Ed.), The SAGE Encyclopedia of Qualitative Research Methods (pp. 434-437). Thousand Oaks, CA: SAGE.

Smith, D. E., \& Turner, S. M. (Eds.). (2014). Incorporating texts into institutional ethnographies. Toronto, ON: University of Toronto Press.

Stewart, J. (2014, August 18). NAPLAN results. Lateline. Retrieved from www.abc.net. au/lateline/content/2014/s4069799.htm. 
Stobart, G. (2008). Testing Times: The uses and abuses of assessment. New York, NY: Routledge.

Taubman, P. M. (2009). Teaching by numbers: Deconstructing the discourse of standards and accountability in education. New York, NY: Routledge.

Thompson, G., \& Cook, I. (2012). Manipulating the data: Teaching and NAPLAN in the control society. Discourse: Studies in the Cultural Politics of Education, 35(1), 1-14.

White, N. (2014). FXDMS wins $\$ 4.8 \mathrm{~m}$ govt contract. ProPrint. Retrieved from www. proprint.com.au/News/389112,fxdms-wins-48m-govt-contract.aspx.

André-Bechely, L. (2005). Could It Be Otherwise? Parents and the Inequities of Public School Choice. New York, NY: Routledge.

Ball, S. J. (2015). Subjectivity as a site of struggle: Refusing neoliberalism? British Journal of Sociology of Education, 37(8), 1129-1146.

Ball, S. J., Maguire, M., Braun, A., \& Hoskins, K. (2011). Policy actors: Doing policy work in schools. Discourse: Studies in the Cultural Politics of Education, 32(4), 625-639.

Bloxham, R., Ehrich, L. C., \& Iyer, R. (2014). Micropolitical insights into Assistant Regional Directors' leadership in Queensland Education. Leading and Managing, 20(1), $32-47$.

Bloxham, R., Ehrich, L., \& Iyer, R. (2015). Leading or managing? Assistant regional directors, school performance, in Queensland. Journal of Educational Administration, 53 (3), 354-373.

Bloxham, T. R. (2013). Leadership of public education: An exploration of executive leaders in Education Queensland. (Doctor of Education thesis, Queensland University of Technology, Brisbane, Australia). Retrieved from https://eprints.qut.edu.au/ 61601/.

Comber, B. (2012). Mandated literacy assessment and the reorganisation of teachers' work: Federal policy, local effects. Critical Studies in Education, 53(2), 119-136.

Connell, R. (2013). The neoliberal cascade and education: An essay on the market agenda and its consequences. Critical Studies in Education, 54(2), 99-112.

Department of Education and Training (DET). (2010). Role Description: Assistant Regional Director, School Performance. Brisbane, QLD.

Department of Education and Training (DET). (2014). Department of Education and Training Performance and Development Cascade. Brisbane, QLD: Queensland Government. Retrieved from http://education.qld.gov.au/staff/development/p erformance/resources/cascade-schools.doc.

Department of Education, Training and Employment (DETE). (2009). Department of Education, Training and Employment (DETE) Annual Report 2008-09. Brisbane, QLD: Queensland Government. Retrieved from http://deta.qld.gov.au/publica tions/annual-reports/08-09/pdf/annual-report-08-09-director-generals-message.pdf.

Department of Education, Training and Employment (DETE). (2011). United in our pursuit of excellence: Agenda for improvement 2012-2015. Brisbane, QLD: Queensland Government. Retrieved from http://education.qld.gov.au/corporate/a bout/pdfs/united-in-our-pursuit-of-excellence.pdf.

Department of Education, Training and Employment (DETE). (2014). Department of Education, Training and Employment (DETE) Annual Report 2013/14. Brisbane, QLD: Queensland Government. Retrieved from http://deta.qld.gov.au/publica tions/annual-reports/13-14/pdf/annual-report-13-14-complete.pdf.

Department of Education. (2015). Key performance indicator cascade 2015-16. Brisbane, QLD: Department of Education. Retrieved from http://deta.qld.gov.au/corp orate/performanceframework/pdf/cascade.pdf. 
Foucault, M. (1982). The subject and power. Critical Inquiry, 8(4), 777-795.

Heffernan, A. (2016). The Emperor's perfect map: Leadership by numbers. The Australian Educational Researcher, 43(3), 377-391.

Kenway, J. (2013). Challenging inequality in Australian schools: Gonski and beyond. Discourse: Studies in the Cultural Politics of Education, 34(2), 286-308.

Kerr, L. (2006). Between caring and counting: Teachers take on educational reform. Toronto, ON: University of Toronto Press.

Lubienski, C. (2013). Privatising form or function? Equity, outcomes and influence in American charter schools. Oxford Review of Education, 39(4), 498-513.

Masters, G. (2009). A shared challenge: Improving literacy, numeracy and science learning in Queensland primary schools. Brisbane, QLD: Queensland Government. Retrieved from http://education.qld.gov.au/mastersreview/pdfs/final-report-masters.pdf.

Nichols, S., \& Berliner, D. (2007). Collateral damage: How high-stakes testing corrupts America's schools. Cambridge, MA: Harvard Education Press.

Nixon, H., \& Kerkham, L. (2014). Literacy assessment that counts: Mediating, interpreting and contesting translocal policy in a primary school. Ethnography and education, 9(3), 343-358.

Queensland Government. (2016). School Enrolment Management Plans. Brisbane, QLD: Queensland Government. Retrieved from http://education.qld.gov.au/ schools/catchment/.

Rose, N. (1996). Inventing our selves: Psychology, power, and personhood. Cambridge, UK: Cambridge University Press.

Sætnan, A. R., Lomell, H. M., \& Hammer, S. (2010). The mutual construction of statistics and society. New York, NY: Taylor \& Francis.

Singh, P., Thomas, S., \& Harris, J. (2013). Recontextualising policy discourses: A Bernsteinian perspective on policy interpretation, translation, enactment. Journal of Education Policy, 28(4), 465-480.

Watt, G., Finger, G., Smart, V., \& Banjer, F. (2014). Project 600: Inspire, connect and transform. Paper presented at the Australian Council for Computers in Education 2014 Conference: Innovating Education, Adelaide, SA. Retrieved from http://acec2014. acce.edu.au/sites/2014/files/attachments/ACEC2014_Project\%20600\%20Inspire\% 20Connect\%20and\%20Transform_Final_Watt_Finger_Smart_Banjer.pdf.

Whitty, G., \& Power, S. (2000). Marketisation and privatisation in mass education systems. International Journal of Educational Development, 20(2), 93-107.

Windle, J. A. (2015). Making sense of school choice. New York, NY: Palgrave MacMillan.

Apple, M. W. (2004). Creating difference: Neoliberalism, neoconservatism and the politics of educational reform. Educational Policy, 18(1), 12-44.

Australian Curriculum Assessment and Reporting Authority (ACARA). (2019). NAPLAN Handbook for Principals. 2019. Retrieved from www.nap.edu.au/verve/ resources/Nationalprotocolsfortestadministration2015-webversion.PDF.

Australian Education Act (2013). (Cwlth). Available from www.comlaw.gov.au/Details/ C2013A00067.

Australian Institute for Teaching and School Leadership (AITSL). (2011). National professional standards for teachers. Canberra, ACT: The Ministerial Council for Education, Early Childhood Development and Youth Affairs (MCEECDYA). Retrieved from www.aitsl.edu.au/australian-professional-standards-for-teachers/standards/list.

Booher-Jennings, J. (2005). Below the bubble: "educational triage" and the Texas accountability system. American Educational Research Journal, 42(2), 231-268. 
Commonwealth of Australia. (2011). Queensland - Reward Targets 2011 - National Partnerships for Literacy and Numeracy. Retrieved from Canberra, ACT: www. federalfinancialrelations.gov.au/content/npa/education/improvingteacherquality/ rewardtargets/2011 Reward Targets Literacy and Numeracy NP - QLD.pdf

Commonwealth of Australia. (2014). Improving Literacy and Numeracy National Partnership. Queensland final report. Retrieved from https://docs.education.gov.au/ system/files/doc/other/qld_ilnnp_final_report_web_accessible.pdf.

Council of Australian Governments (COAG). (2012). National Partnership Agreement on Literacy and Numeracy: Performance report for 2011. Sydney, NSW: COAG Reform Council. Retrieved from http://library.bsl.org.au/jspui/bitstream/1/3451/1/NationalPa rtnershiponLiteracyandNumeracyPerformanceReportfor201130April2012.pdf.

Department of Education and Training. (2014a). Master Teachers. Brisbane, QLD: Queensland Government. Retrieved from http://education.qld.gov.au/staff/devel opment/pdfs/master-teachers-faqs.pdf.

Department of Education and Training. (2014b). Pedagogical Framework. Brisbane, QLD: Queensland Government. Retrieved from http://education.qld.gov.au/curri culum/pdfs/pedagogical-framework.pdf.

Department of Education. (2015). Key performance indicator cascade 2015-16. Brisbane, QLD: Department of Education. Retrieved from http://deta.qld.gov.au/corp orate/performanceframework/pdf/cascade.pdf.

Eacott, S. (2017). School leadership and the cult of the guru: The neo-Taylorism of Hattie. School Leadership \& Management, 37(4), 413-426.

Foucault, M. (1975/1995). Discipline and punish: The birth of the prison (A. Sheridan, Trans.). New York, NY: Vintage Books.

Foucault, M. (1988). Power, moral values, and the intellectual. History of the Present, 4 (1-2), 11-13.

Foucault, M. (1991). Governmentality. In G. Burchell, C. Gordon, \& P. Miller (Eds.), The Foucault effect: Studies in governmentality (pp. 87-104). Hemel Hempstead, UK: Harvester Wheatsheaf.

Gillborn, D., \& Youdell, D. (2000). Rationing education: Policy, practice, reform and equity. Buckingham, PA: Open University Press.

Grissom, J. A., Redding, C., \& Bleiberg, J. F. (2019). Money over Merit? Socioeconomic Gaps in Receipt of Gifted Services. Harvard Educational Review, 89(3), 337-369.

Hardy, I. (2013). A logic of appropriation: Enacting national testing (NAPLAN) in Australia. Journal of Education Policy, 29(1), 1-18.

Hardy, I. (2015). 'I'm just a numbers person': The complexity, nature and effects of the quantification of education. International Studies in Sociology of Education, 25(1), 20-37.

Hogan, A. (2014). NAPLAN and the role of edu-business: New governance, new privatisations and new partnerships in Australian education policy. Australian Educational Researcher, 43(1), 93-110.

Langbroek, J.-P. (2014). Press Release: Master teachers for QLD classrooms. Brisbane, QLD: Queensland Cabinet and Ministerial Directory. Retrieved from http://statem ents.qld.gov.au/Statement/2014/11/2/master-teachers-for-qld-classrooms.

Loveless, T. (2013). How well are American students learning? The 2013 Brown Center Report on American Education, 3(2). Washington, DC: Brookings Institution. Retrieved from www.brookings.edu/ /media/research/files/reports/2013/03/18\%20brown\% 20center\%20loveless/2013\%20brown\%20center\%20report\%20web.pdf.

Marzano, R. J. (2009). Setting the record straight on "high-yield" strategies. Phi Delta Kappan, 91(1), 30-37. 
Marzano, R. J., Pickering, D., \& Pollock, J. E. (2001). Classroom instruction that works: Research-based strategies for increasing student achievement. Alexandria, VA: Association for Supervision and Curriculum Development.

Marzano, R. J., Welch, L., Adams, G., Brown, J. L., \& Welch, A. (2008). The art and science of teaching. Alexandria, VA: Association for Supervision and Curriculum Development.

Nixon, H., \& Kerkham, L. (2014). Literacy assessment that counts: Mediating, interpreting and contesting translocal policy in a primary school. Ethnography and Education, 9(3), 343-358.

Parkinson, H. C., \& Stooke, R. (2012). Other duties as assigned: The hidden work of reading and writing assessments in two primary classrooms. Language and Literacy, 14 (1), 59-77.

Porter, T. M. (2012). Funny numbers. Culture Unbound, 4(4), 585-598. Retrieved from www.cultureunbound.ep.liu.se/v4/a32/cu12v4a32.pdf.

Queensland Government. (2009). Queensland implementation plan: National Partnership for Literacy and Numeracy. Retrieved from https://docs.education.gov.au/ system/files/doc/other/qldstateplanlitnum.rtf.

Queensland Government. (2014). Queensland State Schools Annual Performance Review: Process for teachers. A step-by-step guide. Brisbane, QLD: Queensland Government. Retrieved from http://education.qld.gov.au/staff/development/p erformance/pdfs/step-by-step-guide.pdf.

Sharratt, L. (2018). Leading with knowledge in communities of practice [online]. Australian Educational Leader, 40(4), 12-16.

Sharratt, L. (2019). CLARITY: What matters MOST in learning, teaching and leading. Thousand Oaks, CA: Corwin.

Smith, D. E. (1987). The everyday world as problematic: A feminist sociology. Boston, MA: Northeastern University Press.

Smith, D. E. (Ed.) (2006). Institutional ethnography as practice. New York, NY: Rowman \& Littlefield.

Smith, M. L., Miller-Kahn, L., Heinecke, W., \& Jarvis, P. F. (2004). Political spectacle and the fate of American schools. New York, NY: RoutledgeFalmer.

Tanner, P., \& Vains-Loy, D. (2009). Literacy and Numeracy National Partnership: Curriculum leaders - coaching for success. Retrieved from http://education.qld.gov. $\mathrm{au} /$ staff/development/performance/resources/readings/building-teacher-capacity.pdf.

Ward, D. M. (2012). The effects of standardised assessment (NAPLAN) on teacher pedagogy at two Queensland schools. (Doctoral thesis, Queensland University of Technology, Brisbane, Australia). Retrieved from https://eprints.qut.edu.au/63662/.

Apple, M. W. (2004). Ideology and curriculum (2nd ed.). London, UK: Routledge.

Australian Bureau of Statistics (ABS). (2016). Schools, Australia, 2015. Canberra, ACT: Commonwealth of Australia. Retrieved from www.abs.gov.au/ ausstats/abs@.nsf/m f/4221.0.

Australian Council for Educational Research (ACER). (2012). National School Improvement Tool. Retrieved from www.acer.org/au/school-improvement/imp rovement-tools/national-school-improvement-tool.

Australian Curriculum Assessment and Reporting Authority (ACARA). (2014). NAPLAN 2014 Achievement in reading, persuasive writing, language conventions and numeracy. National report. Retrieved from www.nap.edu.au/_resources/ $\mathrm{Na}$ tional_Assessment_Program_Literacy_and_Numeracy_national_report_for_2014.pdf. 
Australian Institute for Teaching and School Leadership (AITSL). (2011). National professional standards for teachers. Retrieved from www.aitsl.edu.au/australian-p rofessional-standards-for-teachers/standards/list.

Ball, S. J. (2003). The teacher's soul and the terrors of performativity. Journal of Education Policy, 18(2), 215-228.

Bantick, C. (2014a, April 3). Hands up who thinks we teach our students that cheats thrive as NAPLAN prospers? The Courier Mail. Retrieved from www.couriermail. com.au/news/opinion/opinion-hands-up-wh...-cheats-thrive-as-naplan-prospers/ story-fnihsr9v-1226900060938.

Bantick, C. (2014b, May 4). Why I am a NAPLAN cheat. The Age. Retrieved from www. theage.com.au/national/education/why-i-am-a-naplan-cheat-20140501-zr2b4.html.

Calligeros, M. (2014, May 23). Queensland schools accused of NAPLAN cheating. The Brisbane Times. Retrieved from www.brisbanetimes.com.au/queensland/queensla nd-schools-accused-of-naplan-cheating-20140522-zrlnd.html.

Carter, D., Manuel, J., \& Dutton, J. (2018). How do secondary school English teachers score NAPLAN?: A snapshot of English teachers' views. The Australian Journal of Language and Literacy, 41(3), 144-154.

Chilcott, T. (2013, June 29). After concern about students over-practising for the NAPLAN writing test, no forewarning will be issued about its specific style. The Courier Mail. Retrieved from www.couriermail.com.au/news/queensland/after-con cern-about-students-overpractising-for-the-naplan-writing-test-no-forewarning-willbe-issued-about-its-specific-style/story-fnihsrf2-1226671589788.

Comber, B. (2012). Mandated literacy assessment and the reorganisation of teachers' work: Federal policy, local effects. Critical Studies in Education, 53(2), 119-136.

Darling-Hammond, L. (2010). The flat world and education: How America's commitment to equity will determine our future. New York, NY: Teachers College Press.

Department of Education. (2017). Queensland: A state of learning findings from the 2017 school reviews. Retrieved from https://schoolreviews.eq.edu.au/SiteCollectionDocum ents/2017-annual-report-full-report.pdf.

Deveau, J. L. (2008). Examining the institutional ethnographer's toolkit. Socialist Studies, $4(2), 1-19$.

Elmore, R. (2000). Building a new structure for school leadership. Washington, DC: Albert Shanker Institute.

Exley, B., \& Mills, K. A. (2015). Interrogating policy contradictions in literacy reforms about persuasive texts. Paper presented at the American Educational Research Association 2015 Annual Meeting: Towards Justice: Culture, Language and Heritage in Education Research and Praxis, Chicago, IL. Retrieved from http://eprints.qut.edu.au/83769/.

Ferrari, J. (2014, May 12). Busting the NAPLAN myths. The Australian. Retrieved from www.theaustralian.com.au/news/features/busting-the-naplan-myths/ story-e6frg6z6-1226913710635.

Foucault, M. (1969/2002). The archeology of knowledge (A. Sheridan-Smith, Trans.). New York, NY: Harper \& Rowe.

Griffith, A. I., \& Smith, D. E. (2005). Mothering for schooling. New York, NY: RoutledgeFalmer.

Kenway, J. (2013). Challenging inequality in Australian schools: Gonski and beyond. Discourse: Studies in the Cultural Politics of Education, 34(2), 286-308.

Kerr, L. (2006). Between caring and counting: Teachers take on educational reform. Toronto, ON: University of Toronto Press. 
Lipman, P. (2004). High-stakes education: Inequality, globalisation, and urban school reform. New York, NY: RoutledgeFalmer.

Luke, A., Cazden, C., Coopes, R., Klenowski, V., Ladwig, J., Lester, J., MacDonald, S., Phillips, J., Shield, P. G., Spina, N., Theroux, P., Tones, M. J., Villegas, M., \& Woods, A. F. (2013). A summative evaluation of the Stronger Smarter Learning Communities Project. Brisbane, QLD: Queensland University of Technology. Retrieved from http://eprints.qut.edu.au/59535/.

Parkinson, H. C., \& Stooke, R. (2012). Other duties as assigned: The hidden work of reading and writing assessments in two primary classrooms. Language and Literacy, 14 (1), 585-598.

Polesel, J., Dulfer, N., \& Turnbull, M. (2012). The experience of education: The impacts of high-stakes testing on school students and their families. Retrieved from www.whitlam.org/data/assets/pdffile/0008/276191/HighStakesTestingLiteratureRe view.pdf.

Queensland Curriculum and Assessment Authority (QCAA). (2013). NAPLAN 13. Newsletter: August 2013. Brisbane, QLD. Retrieved from www.qcaa.qld.edu.au/ downloads/naplanjul13.pdf.

Queensland Teachers' Union of Employees (QTU). (2015). QTU position statement: The purpose and use of data in Queensland schools. Retrieved from www.qtu.asn. au/files//9514/4072/3124/Positionstatement-Data-July2015.pdf.

Randall, R. (2014, June 16). NAPLAN tests help us to improve vital skills. The Age. Retrieved from www.theage.com.au/national/education/naplan-tests-help-us-imp rove-vital-skills-20140612-zs54n.html.

Renshaw, P., Baroutsis, A., van Kraayenoord, C., Goos, M., \& Dole, S. (2013). Teachers using classroom data well: Identifying key features of effective practices. Final report. Brisbane, QLD: The University of Queensland. Retrieved fromwww.aitsl. edu.au/docs/default-source/default-document-library/teachers-using-classroom-data -well.pdf?sfvrsn $=0$.

Rose, N. (2003). Powers of freedom: Reframing political thought (3rd ed.). Cambridge, UK: Cambridge University Press.

Ryan, M., \& Barton, G. (2013). Working towards a 'thirdspace' in the teaching of writing to middle years students. Literacy Learning: The Middle Years, 21(3), 71-81.

Smith, D. E. (1987). The everyday world as problematic: A feminist sociology. Boston, MA: Northeastern University Press.

Smith, D. E. (1990). Texts, facts and femininity: Exploring the relations of ruling. London, UK: Routledge.

Smith, D. E. (2005). Institutional ethnography: A sociology for people. Oxford, UK: Rowman Altamira.

Smith, D. E., \& Turner, S. M. (Eds.). (2014). Incorporating texts into institutional ethnographies. Toronto, ON: University of Toronto Press.

Smith, J. B., Lee, V. L., \& Newmann, F. M. (2001). Instruction and achievement in Chicago elementary schools. Chicago, IL: University of Chicago.

Stroud, G. (2016). Teaching Australia: Fight or flight?. Griffith Review, 51, 228-237.

Stroud, G. (2019). Teacher: One woman's struggle to keep the heart in teaching. Crows Nest, NSW: Allen \& Unwin.

Thompson, G., \& Harbaugh, A. G. (2013). A preliminary analysis of teacher perceptions of the effects of NAPLAN on pedagogy and curriculum. The Australian Educational Researcher, 40(3), 299-314.

Adam, B. (1990). Time and social theory. Cambridge, UK: Polity Press. 
Bear, D. R., Invernizzi, M., Templeton, S., \& Johnston, F. (2008). Words their way: Word study for phonics, vocabulary and spelling instruction (4th ed.). Upper Saddle River, NJ: Pearson.

Bisaillon, L. (2012). An analytic glossary to social inquiry using institutional and political activist ethnography. International Journal of Qualitative Methods, 11(5), 607-627.

Clay, M. M. (1993). An observation survey of early literacy achievement. Portsmouth, NH: Heinemann.

Clay, M. M. (2001). Running records for classroom teachers. Portsmouth, NH: Heinemann.

Delamont, S., \& Galton, M. (2012). Inside the Secondary Classroom (Vol. 233). New York, NY: Routledge.

Department of Education, Training and Employment (DETE). (2011). United in our pursuit of excellence: Agenda for improvement 2012-2015. Brisbane, QLD: Queensland Government. Retrieved from http://education.qld.gov.au/corporate/a bout/pdfs/united-in-our-pursuit-of-excellence.pdf.

DeVault, M. (Ed.) (2008). People at work: Life power and social inclusion in the New Economy. New York, NY: New York University Press.

Foucault, M. (1988). Power, moral values, and the intellectual. History of the Present, 4 (1-2), 11-13.

Griffith, A. I., \& Smith, D. E. (2005). Mothering for schooling. New York, NY: RoutledgeFalmer.

Hogan, A. (2014). NAPLAN and the role of edu-business: New governance, new privatisations and new partnerships in Australian education policy. Australian Educational Researcher, 43(1), 93-110.

Kerr, L. (2006). Between caring and counting: Teachers take on educational reform. Toronto, ON: University of Toronto Press.

Lipman, P. (2004). High-stakes education: Inequality, globalisation, and urban school reform. New York, NY: RoutledgeFalmer.

Manning, M., McKenzie, M., \& Horne, M. (2013). English Skills Builder: AC Edition. South Melbourne, VIC: Oxford University Press.

Rankin, J. M., \& Campbell, M. (2006). Managing to nurse: Inside Canada's health care reform. Toronto, ON: University of Toronto Press.

Sloan, K. (2006). Teacher identity and agency in school worlds: Beyond the all-good/ all-bad discourse on accountability-explicit curriculum policies. Curriculum Inquiry, 36 (2), 119-152.

Smith, D. E. (2005). Institutional ethnography: A sociology for people. Oxford, UK: Rowman Altamira.

Smith, D. E. (2014, 7-11 July). Anthropology of policy. Paper presented at the Universities in the Knowledge Economy, Ljubljana, Slovenia. Retrieved from unike.au.dk/filea dmin/www.../Ljubljana_Dorothy_Smith_converted.ppt.

Smith, D. E. (Ed.) (2006). Institutional ethnography as practice. New York, NY: Rowman $\&$ Littlefield.

Smith, D. E., \& Turner, S. M. (Eds.). (2014). Incorporating texts into institutional ethnographies. Toronto, ON: University of Toronto Press.

Smith, G. (2014). Policing the gay community: An inquiry into textually-mediated social relations. In D. E. Smith \& S. M. Turner (Eds.), Incorporating texts into institutional ethnographies (pp. 17-40). Toronto, ON: University of Toronto Press.

Smith, J. B., Lee, V. L., \& Newmann, F. M. (2001). Instruction and achievement in Chicago elementary schools. Chicago, IL: University of Chicago. 
Smyth, J. (2006). The politics of reform of teachers' work and the consequences for schools: Some implications for teacher education. Asia-Pacific Journal of Teacher Education, 34(3), 301-319.

Australian Senate Education and Employment Reference Committee. (2014). Effectiveness of the National Assessment Program - Literacy and Numeracy. Final Report. Canberra, ACT: The Australian Government. Retrieved from www.aph.gov.au/Pa rliamentaryBusiness/Committees/Senate/EducationandEmployment/Naplan13/Rep ort/index.

Ball, S. J. (1999). Labour, learning and the economy: A 'policy sociology' perspective. Cambridge Journal of Education, 29(1), 195-206.

Ball, S. J. (2003). The teacher's soul and the terrors of performativity. Journal of Education Policy, 18(2), 215-228.

Ball, S. J. (2015). Subjectivity as a site of struggle: Refusing neoliberalism? British Journal of Sociology of Education, 37(8), 1-18.

Baroutsis, A. (2016). Media accounts of school performance: Reinforcing dominant practices of accountability. Journal of Education Policy, 31(5), 567-582.

Berger, J. (2002). The shape of a pocket. London, UK: Bloomsbury.

Bita, N. (2015a, March 5). Daycare phonetics the perfect preparation for school. The Australian. Retrieved from www.theaustralian.com.au/national-affairs/education/da ycare-phonetics-the-perfect-preparation-for-school/story-fn59nlz9-1227248363538.

Bita, N. (2015b, August 8). National primary curriculum shifts focus to core skills. The Australian. Retrieved from www.theaustralian.com.au/national-affairs/education/na tional-primary-curriculum-shifts-focus-to-core-skills/story-fn59nlz9-1227474939995.

Campbell, M. (2006). Institutional ethnography and experience as data. In D. E. Smith (Ed.), Institutional Ethnography as Practice (pp. 91-107). Lanham, MD: Rowman \& Littlefield.

Carter, D., Manuel, J., \& Dutton, J. (2018). How do secondary school English teachers score NAPLAN?: A snapshot of English teachers' views. The Australian Journal of Language and Literacy, 41(3), 144-154.

Clarke, M. (2014). Novice teachers challenged by ability grouping contrary to evidence. EduMatters: A blog for Australian educational researchers. Australian Association for Educational Researchers. Retrieved from www.aare.edu.au/blog/?p=502.

Comber, B., \& Cormack, P. (2013). High-stakes literacy tests and local effects in a rural school. Australian Journal of Language and Literacy, 36(2), 78-89.

Connell, R. (1985). Teachers' work. Sydney, NSW: Allen \& Unwin.

Desrosières, A. (1998). The politics of large numbers: A history of statistical reasoning (C. Naish, Trans.). Cambridge, MA: Harvard University Press.

Dewey, J. (1916). Democracy and education: An introduction to philosophy of education. New York, NY: Macmillan.

Foucault, M. (1975/1995). Discipline and punish: The birth of the prison (A. Sheridan, Trans.). New York, NY: Vintage Books.

Foucault, M. (2001). Fearless Speech. Los Angeles, CA: Semiotext(e).

Gramsci, A. (1975/1992). Prison Notebooks, Vol. 1 (J. A. Buttigieg \& A. Callari, Trans.). New York, NY: Columbia University Press.

Hacking, I. (1990). The taming of chance. Cambridge, UK: Cambridge University Press.

Hardy, I. (2015). A logic of enumeration: the nature and effects of national literacy and numeracy testing in Australia. Journal of Education Policy, 30(3), 335-362.

Harris, J., Carrington, S., \& Ainscow, M. (2017). Promoting equity in schools: Collaboration, inquiry and ethical leadership. New York, NY: Routledge. 
Hunter, F. (2019, December 9). Education Minister pushes for 'back to basics' approach in schools. The Sydney Morning Herald Online. Retrieved from www.smh.com.au/p olitics/federal/education-minister-pushes-for-back-to-basics-approach-inschools-20191209-p53i7z.html.

Ilanbey, S. (2019, October 8). End the NAPLAN breakaway review, Dan Tehan urges. The Age. Retrieved from www.theage.com.au/national/victoria/end-the-naplan-brea kaway-review-dan-tehan-urges-20191008-p52yt5.html.

Jackson, B. (1964). Streaming. An education system in miniature. London, UK: Kegan Paul. Kenway, J. (2013). Challenging inequality in Australian schools: Gonski and beyond. Discourse: Studies in the Cultural Politics of Education, 34(2), 286-308.

Kerr, L. (2006). Between caring and counting: Teachers take on educational reform. Toronto, ON: University of Toronto Press.

Klenowski, V. (2009). Public education matters: Reclaiming public education for the common good in a global era. The Australian Educational Researcher, 36(1), 1-25.

Lingard, B., Martino, W., Mills, M., \& Bahr, M. (2002). Addressing the educational needs of boys. Canberra, ACT: Department of Education, Science, and Training.

Lipman, P. (2004). High-stakes education: Inequality, globalisation, and urban school reform. New York, NY: RoutledgeFalmer.

Luke, A., Cazden, C., Coopes, R., Klenowski, V., Ladwig, J., Lester, J., MacDonald, S., Phillips, J., Shield, P. G., Spina, N., Theroux, P., Tones, M. J., Villegas, M., \& Woods, A. (2013). A summative evaluation of the Stronger Smarter Learning Communities Project. Brisbane, QLD: Queensland University of Technology. Retrieved from http://eprints.qut.edu.au/59535/.

McGaw, B., Louden, W., \& Wyatt-Smith, C. (2019). NAPLAN Review Interim Report. Retrieved from https://education.nsw.gov.au/about-us/strategies-and-reports/our-rep orts-and-reviews/naplan-review/NAPLAN-Review-Interim-Report.pdf.

McKnight, L., \& Whitburn, B. (2018). Seven reasons to question the hegemony of Visible Learning. Discourse: Studies in the Cultural Politics of Education, 41(1), 32-44.

Margolis, K. (2016). To All My Teaching Buddies [Facebook post]. Retrieved from www.facebook.com/kathy.margolis.7/posts/10208843143294643.

Martyn-Jones, L. (2016, August 15). Queensland schools: Children, 4, get tutors for Prep. The Courier Mail. Retrieved from www.couriermail.com.au/news/queensland/ queensland-schools-children-4-get-tutors-for-prep/news-story/ f120d1576127f383c713e9b51dd2e01f.

Moss, G. (2011). Policy and the search for explanations for the gender gap in literacy attainment. Literacy, 45(3), 111-118.

Neumann, E. (2019). Setting by numbers: Datafication processes and ability grouping in an English secondary school. Journal of Education Policy, doi:10.1080/02680939.2019.1646322.

Porter, T. M. (1996). Trust in numbers: The pursuit of objectivity in science and public life. Princeton, NJ: Princeton University Press.

Randall, R. (2014, June 16). NAPLAN tests help us to improve vital skills. The Age. Retrieved from www.theage.com.au/national/education/naplan-tests-help-us-imp rove-vital-skills-20140612-zs54n.html.

Reid, A. (2002). Public education and democracy: A changing relationship in a globalizing world. Journal of Education Policy, 17(5), 571-585.

Rist, R. (1970). Student social class and teacher expectations: The self-fulfilling prophecy in ghetto education. Harvard Educational Review, 40(3), 411-451.

Scholes, L. (2017). Boys, masculinities and reading: Gender identity and literacy as social practice. New York, NY: Routledge. 
Shine, K. (2015). Are Australian teachers making the grade? A study of news coverage of NAPLAN testing. Media International Australia: Incorporating Culture and Policy, (154), 25-33.

Sloan, K. (2006). Teacher identity and agency in school worlds: Beyond the all-good/ all-bad discourse on accountability-explicit curriculum policies. Curriculum Inquiry, 36 (2), 119-152.

Smith, J. B., Lee, V. L., \& Newmann, F. M. (2001). Instruction and achievement in Chicago elementary schools. Chicago, IL: University of Chicago.

Smyth, J. (2006). The politics of reform of teachers' work and the consequences for schools: Some implications for teacher education. Asia-Pacific Journal of Teacher Education, 34(3), 301-319.

Smyth, J., Dow, A., Hattam, R., Reid, A., \& Shacklock, G. (2000). Teachers' work in a globalising economy. London, UK: Falmer Press.

Spina, N. (2019). 'Once upon a time': Examining ability grouping and differentiation practices in cultures of evidence based decision-making. Cambridge Journal of Education, 49(3), 329-348.

Thomson, S., De Bortoli, L., Underwood, C., \& Schmid, M. (2019). PISA 2018: Reporting Australia's Results. Volume I Student Performance. Camberwell, VIC: Australian Council for Educational Research. Retrieved from https://research.acer.edu. au/ozpisa/35.

Turner, S. (2006). Mapping institutions as work and texts. In D. E. Smith (Ed.). Institutional ethnography as practice (pp. 139-162). Lanham, MD: Rowman \& Littlefield.

Urban, R. (2018, May 14). Under siege but school tests 'key for parents, staff'. The Australian, p. 6.

Watson, A., Kehler, M., \& Martino, W. (2010). The problem of boys' literacy underachievement: Raising some questions. Journal of Adolescent \& Adult Literacy, 53(5), 356. 